\title{
Nutritional Security Options through Agronomic Bio-fortification of Zinc and Iron in Chickpea under Rainfed Areas for Poor and under Nourished Masses of South East Asia-A Review
}

\author{
Brij Nandan*, B. C. Sharma, Gurdev Chand, Akhil Verma, \\ Kapilashiv Bazgalia and Rakesh Kumar
}

PRSS, AICRP on Chickpea, SKUAST-Jammu, Samba 184121, India

*Corresponding author

\section{A B S T R A C T}

\begin{tabular}{|l|}
\hline K e y w o r d s \\
Fortification, \\
$\begin{array}{l}\text { Zinc, Iron, } \\
\text { Micronutrients, } \\
\text { Chickpea }\end{array}$ \\
\hline Article Info \\
\hline $\begin{array}{l}\text { Accepted: } \\
\text { 12 August } 2020 \\
\text { Available Online: } \\
\text { 10 September } 2020\end{array}$ \\
\hline
\end{tabular}

\section{Introduction}

Globally the rainfed region over about 40 percent of the world's land area and host nearly 40 percent of the world's population. Of the 1.5 billion hectare (11 percent of the

world's land surface of 13.4 billion ha) of
Unlike plants, humans also require essential micronutrients and protein for normal physiological functions of the body and general health. Due to low concentration of micronutrients and protein in the staple food, billions of population is lacking sufficient daily intake of micronutrient and protein in their diet sometimes called 'hidden hunger'. Micro nutrient malnutrition is a serious problem to human health throughout the world, primarily in resource limited countries. The micronutrients most commonly associated with human health problems on a global scale include iron, zinc and iodine. Humans require at least 22 mineral elements for their wellbeing. These can be supplied by an appropriate diet. However, it is estimated that over 30 percent of population is zinc ( $\mathrm{Zn}$ ) deficient and rest with other micronutrients. Among micronutrients, $\mathrm{Zn}$ deficiency is occurring in both crops and humans. Zinc deficiency is currently listed as a major risk factor for human health and cause of death globally. According to an estimate of World Health Organization (WHO) during 2015, around two billion people are being suffered with iron and zinc deficiencies and its deficiency ranks $11^{\text {th }}$ among the 20 most important factors in the world and $5^{\text {th }}$ among the 10 most important factors in developing countries like India. $\mathrm{Zn}$ deficiency is widespread in chickpea growing region of the world and is most prevalent among the micronutrients. In the sequence of micronutrient malnutrition; iron is also playing a vital role. Its deficiency is a highly prevalent nutritional disorder afflicting 2.5 to 5 billion people around the globe where poor households and pre-school children are severely affected due to high demand for iron. Iron acts as a co-factor for several enzymes performing basic functions in human body. Inadequate supply of iron contributes to disability, anemia and stunted mental growth. cropland worldwide, 1.223 billion hectare ( 82 percent) is rainfed (FAO, 2015). Further, about 70 percent of the world's staple food continues and will continue to be harvested from rainfed areas, since the scope for further expansion of irrigation is limited due to growing competition for water and the high 
investment cost. The importance of rainfed agriculture varies regionally, and is most significant in Sub-Saharan Africa, where it accounts for about 93 percent of farmed land, 87 percent in Latin America, 67 percent in the Near East and North Africa, 65 percent in East Asia and 58 percent in South Asia (Anon, 2009). Most countries depend primarily on rainfed agriculture for their foodgrain. About 30 percent of the world's land surface ( 4.2 billion hectares) is suitable for rainfed agriculture. Therefore, upgrading rainfed agriculture promises large social, economic and environmental paybacks, particularly in poverty reduction and economic development India ranks first among the rainfed countries in the world in terms of area, but counts amongst the lowest in rainfed yields ( $<1$ ton/ha). As high as 78 million hectare accounting for 64 per cent of the country's net sown area is rainfed (Anonymous, 2017) contributing 44 percent of the total foodgrain production. It is estimated that even after achieving the full irrigation potential; nearly 50 percent of the net cultivated area will remain dependent on rainfall. Cultivation of coarse cereals (91 percent), pulses (91 percent), oilseeds (80 percent) and cotton (65 percent) predominates in these rainfed regions (CRIDA, 2007). In the state of Jammu and Kashmir, rainfed agriculture is practiced over an area of 4.26 lakh hectares which represents 57.64 per cent of the net sown area of 7.39 lakh hectares in the state. Further, out of the total culturalable area of 3.90 lakh hectares in Jammu region 75.25 per cent is rainfed and needs to be judiciously for higher water use efficiency (Nandan et al., 2012). Pulses are produced on 12-15 percent of global arable land and their contribution to total human dietary protein nitrogen requirement is $30 \%$. Most important dietary pulses include chickpea, beans, lentil, green gram (mungbean), black gram (urdbean) field peas, pigeonpea, and cow pea and are also used as protein supplements. The global pulse production, area and yield during 2013 was 73 million tonnes, 80.8 million hectare and $904 \mathrm{~kg} / \mathrm{ha}$, respectively (FAOSTAT 2015). India ranks first in the world's production and area by contributing around 70 percent to the world's total pulses production. Among the different pulses, chickpea is grown in over 40 countries across five continents. India is the leading producer of chickpea accounting for nearly 65.78 and 67.35 percent of the total area (8.52 million hectares) and production (8.83 million tons), respectively (Anonymous, 2015). In the state of Jammu and Kashmir, total area under chickpea is 4 thousand hectares with a production and productivity of 2.51 thousand tones and 6.27 quintals/ha, respectively (Anonymous, 2012-13). It is one of the most important food legume plants in sustainable agriculture system because of its low production cost, wider adaptation, ability to fix atmospheric nitrogen and fit in various crop rotations. It is a rich source of quality protein (20-22 percent) to the predominantly vegetarian population in Indian subcontinent. It has the highest nutritional compositions and free from anti-nutritive components compared to any other dry edible grain legumes, thus, it is considered a functional food or nutraceutical. Besides proteins, it is rich in fiber and minerals (phosphorus, calcium, magnesium, iron and zinc), and its lipid fraction is high in unsaturated fatty acids and has no anti- nutritional factors, and contains higher amounts of carotenoids like $\beta$-carotene than genetically engineered 'Golden rice' (Sandhu et al., 2015).

Unlike plants, humans also require essential micronutrients and protein for normal physiological functions of the body and general health. Due to low concentration of micronutrients and protein in the staple food, billions of population is lacking sufficient daily intake of micronutrient and protein in their diet sometimes called 'hidden hunger' 
(Thavarajah and Thavarajah, 2015; Singh et al., 2015a). Micro nutrition malnutrition is a serious problem to human health throughout the world, primarily in resource limited countries (Kennedy et al., 2003). The micronutrients most commonly associated with human health problems on a global scale include iron, zinc and iodine. Humans require at least 22 mineral elements for their wellbeing (Welch \& Graham, 2004; White \& Broadley, 2005; Graham et al., 2007). These can be supplied by an appropriate diet. However, it is estimated that over 30 percent of population is zinc $(\mathrm{Zn})$ deficient and rest with other micronutrients. Among micronutrients, $\mathrm{Zn}$ deficiency is occurring in both crops and humans (Hotz and Brown, 2004; Welch and Graham, 2004; Shively et al., 2014a). Zinc deficiency is currently listed as a major risk factor for human health and cause of death globally. According to an estimate of World Health Organization (WHO) during 2015, around two billion people are being suffered with iron and zinc deficiencies and its deficiency ranks $11^{\text {th }}$ among the 20 most important factors in the world and $5^{\text {th }}$ among the 10 most important factors in developing countries like India. $\mathrm{Zn}$ deficiency is widespread in chickpea growing region of the world and is most prevalent among the micronutrients. In the sequence of micronutrient malnutrition; iron is also playing a vital role. Its deficiency is a highly prevalent nutritional disorder afflicting 2.5 to 5 billion people around the globe (Yip, 2002) where poor households and pre-school children are severely affected due to high demand for iron (Benoist et al., 2008). Iron acts as a co-factor for several enzymes performing basic functions in human body. Inadequate supply of iron contributes to disability, anemia and stunted mental growth (Sheftela et al., 2011). Malnutrition of above mentioned nutrients is more prevalent in Asian countries where cereals are staple food. In contrast to food security, nutrition security has traditionally been viewed as being within the realm of health professionals. Yet the entire agri-food chain has a vital role to play in addressing this problem. Producing more nutritious food and feed, or 'farming for health', should therefore be a central objective.

Therefore, with this backdrop, there is need to disseminate the different Agronomic Biofortification options for nutritional security. In this context an attempt has been made to compile the information and to put forth in front of the researchers and professional academicians to propagate the same to the ultimate users.

\section{Materials and Methods}

Extensive studies have been conducted to collect the review of literature on the $\mathrm{Zn}$ and Fe fortification and after getting the enough literature the literature is divided into two main headings with Zinc and iron fortification effects on different growth, development, yield and quality parameters of chickpea and allied pulse crops. The each Zinc and Iron components are subdivided into eight sub headings in which the literature is arranged. An attempt has been made to review the effect of foliar nutrition and its impact on nutritional security for more than three decades literature. The extensive survey of library and internet able to collect the results of different scientist and an attempt has been made to compile it for the use of the researchers across the globe

\section{Effect of zinc fertilization on}

Effect of zinc fertilization on growth parameters

Effect of zinc fertilization on plant height of chickpea cultivars

Effect of zinc fertilization on leaf area index of chickpea cultivars 
Effect of zinc fertilization on dry matter accumulation of chickpea cultivars

Effect of zinc fertilization on physiological parameters

Effect of zinc fertilization on yield and yield attributes of chickpea cultivars

Effect of zinc fertilization on quality parameters

Effect of zinc fertilization on relative economics

\section{Effect of Iron fertilization on}

Effect of iron fertilization growth parameters Effect of iron fertilization on plant height of chickpea cultivars

Effect of iron fertilization on leaf area index of chickpea cultivars

Effect of iron fertilization on dry matter accumulation of chickpea cultivars

Effect of iron fertilization on physiological parameters

Effect of iron fertilization on yield and yield attributes of chickpea cultivars

Effect of iron fertilization on quality parameters

Effect of iron fertilization on relative economics

\section{Results and Discussion}

The results of the study are presented in the following heads with proper justification (Fig. 1)

\section{Effect of zinc fertilization on}

\section{Effect of zinc fertilization on growth parameters}

Nourishment of mother plant with balanced nutrition particularly nitrogen, phosphorus and potassium could help proper crop growth, development and cause for exhibiting the potential growth. Increasing levels of fertilizers progressively enhances not only the growth attributes but also seed and stover yield and NPK uptake by seed and stover. Effect of zinc fertilization on the plant height of chickpea cultivars

Field experiment conducted by Habbasha et al., (2013) while working in Egypt, to access the effect of foliar application of Zinc at different growth stages in chickpea crop and reported a significant increase in plant height of chickpea over the control treatments. It was reported that application of nitrogen levels in combination with $\mathrm{Zn}$ as foliar application either at flowering or seed filling stages exhibited significant increases in most of the growth characters as compared to without $\mathrm{Zn}$ application. Hadi et al., (2013), while studying the effects of zinc application on yield and yield components of Chickpea also reported that zinc had positive effects on plant height. Studies conducted by Kayan et al., (2015), in Turkey, under dryland conditions, to determine the effect of foliar application of zinc on the yield of chickpea crop, reported a significant difference in growth parameters like plant height of chickpea. Hossain et al., (2016), while working on sandy loam soils Bangladesh, to study the effect of boron and zinc on the growth and yield of chickpea noticed that zinc showed significant effect on plant height of chickpea.

In a study conducted by Sajid et al., (2016) to access the influence of zinc fertilization in vegetable crop revealed that highest plant height was observed in plants that receive zinc foliar spray as compared to the control plants where no zinc was applied. In contrast to above findings, El- Tohamy et al., (2009) reported that plant height of vegetable crop significantly increased by the application of $\mathrm{Zn}$ as compared to control plants.

Effect of zinc fertilization on the leaf area index of chickpea cultivars

Experiments conducted by Jha et al., (2015) on clay loam soils of Udaipur, recorded 
highest leaf area index with treatment where zinc was applied as foliar spray as compared to the rest of the treatments. Studies conducted by Sajid et al., (2016), at Peshawar, to access the influence of zinc fertilization revealed that more number of leaves were observed in plants where zinc was applied as foliar spay as compared to the control plants. In contrast to above findings, Yousaf et al., (2007) who found that zinc foliar application significantly enhanced the leaf area index. Similarly, Alam et al., (2010) found the response of micronutrients for vegetable crop leaf area index are significantly influenced by the application of $\mathrm{Zn}$.

\section{Effect of zinc fertilization on the dry matter accumulation of chickpea cultivars}

Enania et al., (1994) while working on calcareous soils of Udaipur, reported the application of 5.0 and $7.0 \quad \mathrm{~kg} \quad \mathrm{Zn} / \mathrm{ha}$ significantly increased the dry matter of chickpea by upto 6.87 and $7.34 \mathrm{~g} /$ plant respectively over control and $2.5 \mathrm{~kg} \mathrm{Zn} / \mathrm{ha}$ as dry matter of 5.92 and $6.37 \mathrm{~g} /$ plant respectively. Experiments was conducted by Khan et al., (2003), in Australia, to access the effect of zinc fertilization in chickpea crop and reported that there was a significant increase in dry matter production with application of zinc. Field experimentation on sandy loam soils of Bikaner conducted by Balai et al., (2017), to access the influence of zinc fertilization and found that increasing dose of zinc up to $6 \mathrm{~kg} / \mathrm{ha}$ significantly increased the dry matter accumulation at 60, 90 and 120 DAS over the control treatment. Jha et al., (2015) while working on clay loam soils of Udaipur recorded significantly higher dry matter accumulation by the application of zinc over the rest of the treatments. Hossain $e t$ al., (2016) conducted study on sandy loam soils of Bangladesh and found that dry matter accumulation increased with the application of zinc over the control treatments.

\section{Effect of zinc fertilization on physiological parameters}

Study was carried out by Ingle et al., (2016), to determine the "Effect of foliar application zinc and iron on growth yield and quality of gladiolus grown on Vertisol", during Rabi season 2013-14 at Bhajiwadi of Horticulture, College of Agriculture, Nagpur (Maharashtra), India. The experiment was laid out in FRBD with three replication consistent four levels of zinc and iron viz., $\mathrm{Zn}_{0}-1$ (water spray) $\mathrm{Zn}_{1}-0.5 \%, \mathrm{Zn}_{2}-1.0 \%, \mathrm{Zn}_{3}-1.5 \%$ and $\mathrm{Fe}_{0^{-}}$(water spray), $\mathrm{Fe}_{1^{-}}-0.5 \%, \mathrm{Fe}_{2^{-}}-1.0 \%$ and $\mathrm{Fe}_{3}-1.5 \%$. The result showed that days required for first spike emergence in gladiolus was significantly influenced by application of various levels of zinc and the treatment $\mathrm{Zn}_{2}$ took required significantly minimum days (63.17 days) for emergence, which was of first spike and it found statistically at par with the treatments $\mathrm{Zn}_{1}$ (67.83 days) and the treatment $\mathrm{Zn}_{3}$ (66 days). Whereas, the treatment $\mathrm{Zn}_{0}$ took maximum days for emergence of first spike (71.25 days). Application of zinc resulted in early in flowering in gladiolus and the first spike emergence was noted with application $1.0 \%$ zinc, which might be due to the fact that, zinc plays vital role in growth and development of plant because of its stimulatory and catalyst effect in various physiological and metabolic process of plan. Experiment was carried out by Sajid et al., (2016), at New Developmental Farm (NDF) Horticulture section Khyber Pakhtunkhwa, Agricultural University Peshawar, during summer 2011 to study the influence of zinc as soil and foliar application on growth and yield of okra. The data on number of days to $50 \%$ flowering indicated that significant differences were observed in okra with different levels of zinc, methods of application as well as their interaction. The highest number of days (51.5days) to $50 \%$ flowering was observed in plots where zinc was applied as soil while the foliar application of zinc resulted in earlier $50 \%$ flowering 
(50.1days). The flowering delayed (51.2days) in control plants (untreated with zinc) and it was at par with the plots each received zinc at the rate of 4,6 , and $8 \mathrm{~kg} / \mathrm{ha}$ but statistically different from plots where zinc applied at the rate of $2 \mathrm{~kg} / \mathrm{ha}$, where earlier flowering occur (49.83).

\section{Effect of zinc fertilization on the yield and yield attributes of chickpea cultivars}

Kushwaha (1997) showed that application of zinc sulphate at $25 \mathrm{~kg} / \mathrm{ha}$ increased the productivity upto 22.2 per cent over the control in chickpea. Sakal et al., (1998) found that application of zinc progressively increased the grain yield of chickpea from 14.5 to $19.0 \mathrm{q} / \mathrm{ha}$ and straw yield from 16.0 to $22.0 \mathrm{q} / \mathrm{ha}$. The grain yield response ranged between 150 to $450 \mathrm{~kg} / \mathrm{ha}$ as zinc dose increased from 2.5 to $10 \mathrm{~kg} / \mathrm{ha}$. Zinc @ $5 \mathrm{~kg}$ was found as ideal dose for chickpea. Brennan et al., (2001) reported that the relative response of chickpea to $\mathrm{Zn}$ application is greater than that of other crops. $\mathrm{Zn}$ application resulted in more vegetative growth, leading to greater yield. Experiments was conducted by Khan et al., (2003) in Australia, to assess the effect of Zinc fertilization in chickpea crop and reported that there was a significant increase in grain yield with the application of zinc when there was adequate moisture. They also found that application of Zinc resulted in improved water use efficiency in chickpea crop. Field experiments were conducted by Sangwan et al., (2004), during rabi seasons at Dryland Research Farm of CCS Haryana Agricultural University, Hisar located in an arid climate to evaluate the effect of $\mathrm{Zn}$ appreciation to soil $(0,5,10$ and $15 \mathrm{~kg} \mathrm{Zn/ha)} \mathrm{on} \mathrm{chickpea} \mathrm{yield}$ under dryland conditions. It was reported that the grain yield of chickpea increased significantly with various levels of $\mathrm{Zn}$ application when compared with the control. The result also showed that a mean grain yield increase of $35 \%$ was observed with zinc fertilization over control. Valenciano et al., (2010) conducted an experiment on loamy soil conditions of Spain, to evaluate the response of Zinc application on chickpea crop under pot condition, and the results showed that application of zinc enhances yield attributes viz; pods/plant, 1000-seed weight and finally the seed yield of Chickpea. It was also observed that the soil application of $\mathrm{Zn}$ increases growth due to increase in dry weight of pods including seeds. The lowest plant yield was obtained when the $\mathrm{Zn}$ application was not carried out (2.55 g/plant). Chickpea yield increased with the incremental increase in the application of $\mathrm{Zn}$ to until $\mathrm{Zn}_{4}$ (3.23 g/plant). Ramaprasad et al., (2011) revealed that soil application of $25 \mathrm{~kg} \mathrm{ZnSO}$ /ha along with $0.5 \% \mathrm{ZnSO}_{4}$ foliar spray of twice (45 and 55 DAS) proved significantly superior over the control in seed yield (3046 kg/ha) in kabuli chickpea under clay loam soils of Andhra Pradesh. Study carried out by Valenciano et al., (2011) in the province of Leon, Spain, under the field conditions, with the aim of determining whether the application of Zinc ( $\mathrm{Zn}$ ) improved chickpea growth and yield. The results showed that, at maturity, plants fertilized with $\mathrm{Zn}$ had a greater total dry matter production and seed yield, mainly due to increment in pod dry matter. Shaban et al., (2012) conducted a field experiment on clay soil, in Bu-Ali Sina University of Hamedan, Iran, to determine the effects of Zinc fertilizer on yield and yield components of chickpea. It was found that application of Zinc fertilizer had better effect on grain yield, yield components and biomass yield increased with application of it significantly. Among the $\mathrm{Zn}$ fertilizer treatments, the highest grain yield (3526 $\mathrm{kg} / \mathrm{ha}$ ) was belonged to the $\mathrm{Zn}_{1}$ treatment and the lowest grain yield $(3125 \mathrm{~kg} / \mathrm{ha})$ was belonged to the $\mathrm{Zn}_{0}$ treatment. $\mathrm{A}$ field experiment was conducted by Parimala et al., (2013), at Seed Research and Technology 
Centre, Rajendranagar, Hyderabad (A.P.), India to study the effect of macro and micronutrients on yield and seedling quality parameters of chickpea variety JG-11. The result showed that $\mathrm{Zn}(0.5 \%)$ enhanced the number of pods/plant and led to maximum seed yield/plant compared to all other treatments. Application of zinc enhanced the root growth, nodulation and nitrogen content of nodules indirectly contributing to the increased yield. Pooniya and Shivay (2012) carried out a field experiment during the rainy season of 2008 and 2009 at a research farm of the Indian Agricultural Research Institute, New Delhi on study the eff ects of summer green-manuring crops and zinc $(\mathrm{Zn})$ fertilization on the productivity and economics of basmati rice with four treatments comprising summer greenmanuring residue incorporation and eight treatments of $\mathrm{Zn}$ fertilization, i.e. absolute control (no $\mathrm{N}$ and no $\mathrm{Zn}$ ), control (only $\mathrm{N}$ ), $2.0 \% \mathrm{Zn}$-enriched urea (ZEU) $\left(\mathrm{ZnSO}_{4} \cdot \mathrm{H}_{2} \mathrm{O}\right)$, $2.0 \% \mathrm{ZEU}(\mathrm{ZnO}), 5 \mathrm{~kg} \mathrm{Zn} / \mathrm{ha}\left(\mathrm{ZnSO}_{4} \cdot \mathrm{H}_{2} \mathrm{O}\right)$ as soil application, $5 \mathrm{~kg} \mathrm{Zn} / \mathrm{ha}(\mathrm{ZnO})$ as soil application, $\mathrm{ZnO}$ slurry for dipping rice seedling roots before transplanting of basmati rice and $0.2 \%$ foliar spray of $\mathrm{ZnSO}_{4} .7 \mathrm{H}_{2} \mathrm{O}$ at maximum tillering, pre-flowering and flowering stage and reported that significant increase in plant height due to $\mathrm{Zn}$ fertilization in both years. The highest plant height, high number of tillers and higher dry matter accumulations at 30,60 and 90 days after transplanting was observed with $2.0 \%$ ZEU $\left(\mathrm{ZnSO}_{4} \cdot \mathrm{H}_{2} \mathrm{O}\right)$ in 2008 and 2009 , respectively. Conducted studies by Pathak et al., (2012), in Lucknow, reported an increase in grain yield of chickpea due to $\mathrm{Zn}$ application. Foliar application of $\mathrm{ZnSO}_{4}$ to zinc deficient plants at the time of initiation of flowering partially reverses the adverse effect of zinc deficiency on pollen-stigma morphology, pollen fertility, and greatly enhanced seed yield of plants. It was reported that in comparisons with the plants given low $\mathrm{Zn}$ supply, the number and weight of pods and seeds formed was high in plants given sufficient $\mathrm{Zn}$ supply. Habbasha $e t$ al., (2013) while working in Egypt, studied the effect of foliar application of Zinc at different growth stages in chickpea crop and reported a significant increase in number of pods/plant, weight of pods/plant, seed yield /plant, seed and straw yields. It was reported that application of nitrogen levels in combination with $\mathrm{Zn}$ as foliar application either at flowering or seed filling stages exhibited significant increases in most of the growth characters as compared to without $\mathrm{Zn}$ application. Hadi et al., (2013) while studying the effects of zinc application on yield and yield components of Chickpea also reported that zinc had positive effects on seed yield. In a study conducted by Kharol et al., (2014) to study the effect of sulphur and zinc on yield, quality and nutrient content and uptake by chickpea (Cicer arietinum L.) was conducted during rabi season of 2011-12 at the instructional Farm of R. C. A., Udaipur with four levels of sulphur $(0,15,30$ and $45 \mathrm{~kg}$ $\mathrm{S} / \mathrm{ha})$ and zinc $(0,2.5,5.0$ and $7.5 \mathrm{~kg} \mathrm{Zn} / \mathrm{ha})$. It was observed that the maximum number of branches per plant (22.22) was observed with the application of $7.5 \mathrm{~kg} \mathrm{Zn} / \mathrm{ha}$ but it was found at par with $5 \mathrm{~kg} \mathrm{Zn} / \mathrm{ha}$. The test weight of grain $(\mathrm{g})$ increased significantly up to $5 \mathrm{~kg}$ $\mathrm{Zn} / \mathrm{ha}$ which was at par with $7.5 \mathrm{~kg} \mathrm{Zn} / \mathrm{ha}$. It was significantly superior to rest of the zinc levels. Application of $5 \mathrm{~kg} \mathrm{Zn} / \mathrm{ha}$ significantly increased seed yield over control and $2.5 \mathrm{~kg}$ $\mathrm{Zn} /$ ha by 25.20 and $12.55 \%$, respectively. The effect of application of 5 and $7.5 \mathrm{~kg} \mathrm{Zn} / \mathrm{ha}$ was found at par. Studies was conducted by Shivay et al., (2014) at IARI, New Delhi, to study the effect of varieties and levels of Zinc $(\mathrm{Zn})$ application on the grain yield in chickpea (Cicer arietinum L.) and reported significant enhancement in growth characters. The result showed that with each successive increase in the application of $\mathrm{Zn}$ from 2.5 to $7.5 \mathrm{~kg} / \mathrm{ha}$ also increased the grain as well as straw yields of chickpea. $\mathrm{Zn}$ application 
significantly improved yield attributes, grain and straw yields. The study also brings out that Zinc application not only increases the grain yield in chickpea but as leads to $\mathrm{Zn}$ fortification of grains. Field experiment was conducted by Shivay et al., (2014), at the Indian Agricultural Research Institute, New Delhi, to study the effect of genetic variability and Zinc use efficiency in Chickpea as influenced by Zinc fertilization and the result showed that with each successive increase in the application of $\mathrm{Zn}$ from 2.5 to $7.5 \mathrm{~kg} / \mathrm{ha}$ also increased the grain as well as straw yields of Chickpea. However, the significantly highest grain yield (2.24 t/ha, mean of 2 years) was recorded with application of $7.5 \mathrm{~kg} \mathrm{Zn} / \mathrm{ha}$ which was 18.52 , 1089 and $4.19 \%$ higher compared to $0,2.5$ and $5.0 \mathrm{~kg} \mathrm{Zn/ha}$ respectively. Alam and Kumar (2015) studied on effect of zinc on growth and yield of at Saran district of Bihar with four treatments $\left(0 \mathrm{~kg} / \mathrm{ha} \mathrm{ZnSO}_{4}, 05\right.$ $\mathrm{kg} / \mathrm{ha} \mathrm{ZnSO}_{4}, 10 \mathrm{~kg} / \mathrm{ha} \mathrm{ZnSO}_{4}$ and $20 \mathrm{~kg} / \mathrm{ha}$ $\mathrm{ZnSO}_{4}$ ) and show that the highest growth parameters included plant height $(\mathrm{cm})$, plant dry weight $(\mathrm{g})$, number of tillers $/ \mathrm{m}^{2}$, number of effective tillers $/ \mathrm{m}^{2}$ with application of 10 $\mathrm{kg} / \mathrm{ha} \mathrm{ZnSO}_{4}$. It has been reported that higher dose of $\mathrm{ZnSO}_{4}$ gave higher yield components. The results showed that the seed yield was greater in $0.4 \%$ among Zinc doses. An experiment was conducted by Hossain et al., (2016), at the Agronomy Field Laboratory, Department of Agronomy and Agricultural Extension, University of Rajshahi during the period from November 2013 to April 2014 to study the effect of boron and zinc on the growth and yield of chickpea. It has been reported that Zinc showed significant effect on almost all the yield attributes and yield of chickpea. The highest seed yield (1.742 t/ha) was obtained from $4 \mathrm{~kg} \mathrm{Zn}$ ha and lowest one $(1.325 \mathrm{t} / \mathrm{ha})$ was found in control treatment. The highest plant height, number of primary branches/plant, number of secondary branches/plant, number of pod/plant,1000- seed weight, stover yield and biological yield were obtained from the application of $4 \mathrm{~kg}$ $\mathrm{Zn} / \mathrm{ha}$. Control treatment gave the lowest result regarding all these parameters. Zinc doses exerted significant influence on seed yield of chickpea. From the result of the experiment we can see that the highest seed yield was obtained from the application of 4 $\mathrm{kg} \mathrm{Zinc/ha}$ and the lowest seed yield was obtained from control treatment. A field experiment was conducted by Balai et al., (2017), at Agronomy farm, College of Agriculture, Bikaner during Rabi, 2009-10 and it was reported that increasing dose of zinc up to $6 \mathrm{~kg} / \mathrm{ha}$ significantly increased the yield (grain, straw and biological yield). it was also found that the numbers of seed per pod increase significantly in same manner of pods per plant due to application of $6.0 \mathrm{~kg}$ $\mathrm{Zn} / \mathrm{ha}$ over control and $3.0 \mathrm{~kg} \mathrm{Zn/ha} \mathrm{by} 21.16$ and 7.79 per cent, respectively. Application of $6.0 \mathrm{~kg} \mathrm{Zn} / \mathrm{ha}$ produced significantly higher seed yield (1409.92 kg/ha), straw yield $(2335.00 \mathrm{~kg} / \mathrm{ha})$ and biological yield (3744.92 $\mathrm{kg} / \mathrm{ha}$ ), which was significantly superior of the rest of treatments.

\section{Effect of zinc fertilization on quality parameters}

Sakal et al., (1980) corroborated that zinc uptake by seed and stover of chickpea progressively increased with $\mathrm{Zn}$ foliar application. Enania and Vyas (1994) reported that the application of zinc upto $7.5 \mathrm{~kg} / \mathrm{ha}$ significantly increased the $\mathrm{Zn}$ uptake by chickpea crop. This might be due to the fact that increasing levels of zinc increased its concentration in the soil solution which intern increased the absorption of zinc by plants in calcareous soils of Udaipur. Mehdi et al., (1990) reported that the relative effectiveness of $\mathrm{Zn}$ sources decreased in the following order: $\mathrm{Zn}-\mathrm{EDTA}>\mathrm{Zn}\left(\mathrm{NO}_{3}\right)_{2}>\left(\mathrm{NH}_{4}\right)_{2} \mathrm{ZnO}_{2}>$ $\mathrm{ZnSO}_{4}>\mathrm{ZnCl}_{2}$. Singh et al., (1992) reported that the concentration and plant uptake of $\mathrm{Zn}$ 
were increased by $\mathrm{Zn}$ application in chickpea plant. Singh et al., (1997) opined that application of $5 \mathrm{~kg} \mathrm{Zn}$ ha-1 has significantly increased that the seed protein yields of pulses over control. Srivastava et al., (1999) also studied the comparative efficiency of different sources of $\mathrm{Zn}$ for lowland rice production. They reported that Zn-EDTA was the most efficient source of $\mathrm{Zn}$ for lowland rice production. Conducted studies by Khan et al., (2003) in Australia on effect of Zinc fertilization on grain yield and seed $\mathrm{Zn}$ content in chickpea showed that increasing the soil zinc from $0.1 \mu \mathrm{g} \mathrm{Zn} / \mathrm{g}$ to $2.5 \mu \mathrm{g} \mathrm{Zn} / \mathrm{g}$ increased the mean seed $\mathrm{Zn}$ concentration from 8.5 to $46 . \mu \mathrm{g} \mathrm{Zn/g}$ in seed of chickpea. They also reported that largest portion of applied Zinc was found in the seeds of chickpea, which can be a beneficial nutritional trait for human nutrition. Akay A. (2011) studied the effect of zinc fertilizer applications on different chickpea varieties and the most suitable zinc application dose were investigated under the field conditions in May to September of 2003 and 2004. The results showed that the chlorophyll content in the leaves showed a significant difference among the varieties for both years $(\mathrm{P}<$ 0.01). The values of Phosphorus, phytic acid and $\mathrm{Zn}$ contents in the seed and the $\mathrm{Zn}$ content in the leaf of ILC-482 variety were found to be higher when compared with other varieties Zhao et al., (2011) reported that the $\mathrm{Zn}$ fertilization significantly increased the amount of soil diethylene tri amine penta acetic acid-Zn (DTPA-Zn), whereas there was no significant effect on $\mathrm{Zn}$ concentration in grain. Furthermore, the utilization rate of $\mathrm{Zn}$ fertilizer was only $0.98 \%, 0.64 \%, 0.29 \%$, and $0.14 \%$ with treatments of $7.5,15,30$, and 45 $\mathrm{mg} \mathrm{Zn} / \mathrm{ha}$, respectively. In contrast, the hydroponic experiment showed that both foliar spray and $\mathrm{Zn}$ supplied to roots significantly increased $\mathrm{Zn}$ concentration in grain, with the greatest concentration found in shoots. Results suggested that lower absorption and translocation were the inhibitory factors to increase grain $\mathrm{Zn}$ concentration in calcareous soil. Studies Conducted by Pathak et al., (2012), in Lucknow, to see the effect of zinc foliar application on improving plant yield and seed zinc content for human consumption and reported that Zinc foliar application improved not only the boldness and vigor of seeds in zinc-deficient plants, but also the seed zinc content in zinc-deficient seeds as well as the sufficient ones. There was an increase in $\mathrm{Zn}$ concentration in the leaves and seeds after $\mathrm{Zn}$ foliar application to $\mathrm{Zn}$ deficient as well as $\mathrm{Zn}$ sufficient plants. Zn concentration increased from $10 \mu \mathrm{g} / \mathrm{dry}$ weight in $\mathrm{Zn}$ deficient seeds to $35 \mu \mathrm{g} / \mathrm{g}$ dry weight in $\mathrm{Zn}$ deficient foliar seeds. Roy et al., (2013) reported that application of Zn @ 0, $5.5 \mathrm{~kg}, 22 \mathrm{~kg} \mathrm{Zn/ha,}$ $0.1 \% \mathrm{Zn}$ foliar application and $5.5 \mathrm{~kg} \mathrm{Zn}+$ $0.1 \% \mathrm{Zn}$ spray, increased the yield, concentration and its uptake in seed and straw in all the green gram genotypes. Maximum $\mathrm{Zn}$ concentration in straw and seed (5.48 and 3.5 folds over control) was achieved when combined application of soil + foliar was made. Soil + foliar application of $\mathrm{Zn}$ increased the seed crude protein by $26.9 \%$ over control. A field experiment was conducted by Gowda et al., (2014), during kharif 2012-13 at the Agricultural College Farm, Raichur, to study the response of pulses to soil application of micronutrients and foliar spray of macronutrients on yield, yield components, protein yield and economics. The results revealed that the soil application of ZnSO4@ 25 kg/ha along with foliar spray of 19:19:19@ 0.4\% recorded significantly higher protein content $(22.47 \%)$, protein yield $(288.75 \mathrm{~kg} / \mathrm{ha})$,higher leaf area per plant (27.23 $\mathrm{dm}^{2}$ /plant) and higher chlorophyll content (66.43 \%). Paramesh et al., (2014) advocated that $25 \mathrm{~kg} \mathrm{ZnSO} 4.7 \mathrm{H}_{2} \mathrm{O} /$ ha soil has recorded significantly higher seed zinc (101 $\mathrm{g} / \mathrm{ha}$ ), protein $(9.0 \%)$ and protein yield (379 $\mathrm{kg} / \mathrm{ha}$ ) in maize crop, but it was at par with 
$12.5 \mathrm{~kg} \mathrm{ZnSO} \mathrm{Zn}_{4} 7 \mathrm{H}_{2} \mathrm{O} / \mathrm{ha}$ soil $+0.5 \%$ $\mathrm{ZnSO}_{4} .7 \mathrm{H}_{2} \mathrm{O}$ foliar spray and the lower protein, protein yield was found in the control plots. Studies conducted by Shivay et al., (2014) at IARI, New Delhi, to study the effect of varieties and levels of $\mathrm{Zinc}(\mathrm{Zn})$ on protein content, $\mathrm{Zn}$ and nitrogen uptake by chickpea (Cicer arietinum L.) and reported significant enhancement in $\mathrm{Zn}$ concentration in grains and straw. The study further indicates that there was high Zinc uptake, protein yield and protein content in chickpea grains over control treatments. It was found that each successive level of $\mathrm{Zn}$ application increase $\mathrm{Zn}$ concentration in Chickpea straw upto $7.5 \mathrm{~kg}$ $\mathrm{Zn} / \mathrm{ha}$. $\mathrm{Zn}$ concentration in chickpea grain increased from $38.6 \mathrm{mg} / \mathrm{kg}$ in no $\mathrm{Zn}$ (check) to $48.4 \mathrm{mg} / \mathrm{kg}$ with an application of $7.5 \mathrm{~kg}$ $\mathrm{Zn} /$ ha.

Dadkhah et al., (2015) studied the effect of water deficit stress and foliar application of zinc on physiological characteristics of chickpea in field crop research station of University of Mohaghegh Ardabili. In this study proline, lysine, methionine, soluble sugars, and protein content were measured. The result showed that Spraying $6 \mathrm{~kg} / \mathrm{ha}$ zinc sulphate also enhanced the amount of proline, soluble sugar and osmotic potential of Chickpea plants. Fasaei et al., (2015) studied the effect of Zinc treatments on the growth and nutrient composition of chickpea in a greenhouse and reported that the application of $\mathrm{Zn}$ increased mean $\mathrm{Zn}$ uptake in chickpea shoot. Application of $10 \mathrm{mg} \mathrm{Zn/} \mathrm{kg} \mathrm{increased}$ mean $\mathrm{Zn}$ uptake of aboveground tissues by $73 \%$ and $123 \%$ respectively. Kayan et al., (2015) conducted an experiment on Chickpea crop in Turkey to evaluate the effect of foliar application of $\mathrm{Zn}$ and reported that increased zinc doses caused an increase in Zinc content of seed and also concluded that foliar application of Zinc resulted in an increase in seed mineral content viz. $\mathrm{Zn}, \mathrm{Fe}, \mathrm{P}$ and $\mathrm{N}$ contents in seed of Chickpea. The results also showed that the highest $\mathrm{Zn}, \mathrm{Fe}$ and $\mathrm{P}$ content in seed was detected in $0.6 \%$. To study the effects of foliar application of zinc on yield, yield components and grain quality of chickpea (Cicer arientinum L.), Shirani et al., (2015), conducted two experiments, one in autumn and the other in spring were conducted at Research Farm, Shahrekord University in 2009-2010 growing season and it was concluded that the Foliar application of zinc sulphate significantly increased $\mathrm{Zn}$ content of grains. A field experiment was conducted by Singh et al., (2015), during two consecutive rabi seasons of 2012-13 and 2013-14 at New Research Farm, ICAR-Indian Institute of Pulses Research, Kanpur, Uttar Pradesh, to study the effect of diverse combinations of foliar fertilization on growth, yield attributes, yield, nutrient partitioning and nutritional enrichment of chickpea.it was concluded that foliar fertilization with zinc significantly improved the concentration in stem, leave and root of the chickpea plant. Further, foliar spray with zinc significantly enhanced concentration of protein, zinc and iron, respectively over no spray. It was reported that without $\mathrm{Zn}$ spray, $\mathrm{Zn}$ concentration in grain recorded only 27.12 $\mathrm{mg} / \mathrm{kg}$ but when zinc was sprayed the $\mathrm{Zn}$ concentration improved $(32.48 \mathrm{mg} / \mathrm{kg})$.

Experiment was conducted by Choudhary et al., (2016), during rabi seasons of 2012-13 and 2013-14 to study the effect of zinc fertilization on quality, nutrient uptake, profitability and moisture use indices of chickpea under limited moisture conditions. It was found that direct application of $5.0 \mathrm{~kg}$ $\mathrm{Zn} / \mathrm{ha}$ significantly improved the protein content in grain during 2013-14 and protein yield, total uptake of $\mathrm{N}$ and $\mathrm{P}$ over lower levels. Conducted experiment by Balai et al., (2017), at Agronomy farm, College of Agriculture, Bikaner during Rabi, 2009-10 reported that the application of $6 \mathrm{~kg} \mathrm{Zn} / \mathrm{ha}$ recorded significant increase in chlorophyll 
content in Chickpea plants. In an experiment conducted by Kharol et al., (2014), to study the effect of sulfur and zinc on yield, quality and nutrient content and uptake by chickpea (Cicer arietinum L.) during rabi season of 2011-2012. The results indicated that application of increasing levels of sulfur and zinc increased the grain yield, protein content, nutrient content and nutrient uptake of chickpea. Field experiments were conducted by Hidoto et al., (2017) at three locations with $\mathrm{Zn}$ deficient soils in southern Ethiopia during 2012 and 2013 cropping seasons to evaluate the effects of $\mathrm{Zn}$ fertilization strategies and varietal differences on $\mathrm{Zn}$ content and plant performance of chickpea (Cicer arietinum L.). The result showed that Zinc application strategy significantly influenced both grain and straw $\mathrm{Zn}$ concentrations. Accordingly, Zinc foliar application increased grain $\mathrm{Zn}$ content by 21 and $22 \%$ over $\mathrm{Zn}$ soil application and seed priming, respectively. Moreover, foliar application resulted in 383 and $437 \%$ increase in straw $\mathrm{Zn}$ content over soil application and seed priming methods, respectively.

Fig.1

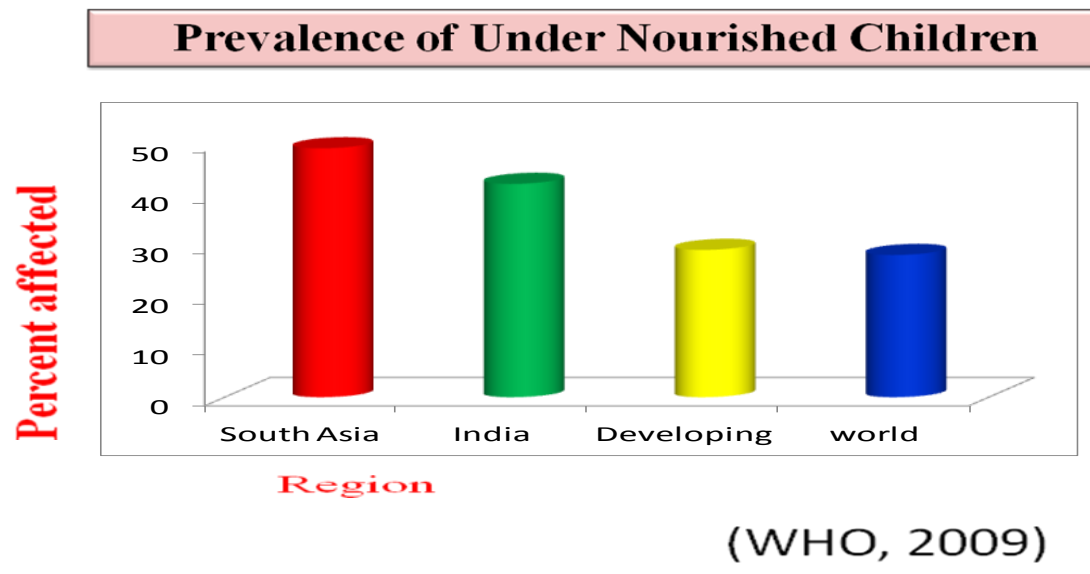

Effect of zinc fertilization on relative economics

Naik and Das (2008) reported that the highest cost-benefit ratio was 1.71 with basal application of $0.5 \mathrm{~kg} \mathrm{Zn/ha}$ as Zn-EDTA. With regards to modes of application of $\mathrm{ZnSO}_{4}$, split application of 10 and $20 \mathrm{~kg}$ $\mathrm{Zn} / \mathrm{ha}$ as $\mathrm{ZnSO}_{4}$ resulted in a higher costbenefit ratio of 1.32 and 1.21 , respectively, over the corresponding basal applications. However, basal application of $1.0 \mathrm{~kg} \mathrm{Zn} \mathrm{ha}^{-1}$ as Zn-EDTA resulted in a higher cost-benefit ratio of 1.69 over its corresponding split application. Yadav et al., (2010) reported that the economic return was highest at the $1.0 \%$ level in the case of $\mathrm{ZnSO}_{4}$, and at the $2.0 \%$ level in case of $\mathrm{ZnO}$. Further, $1.0 \% \mathrm{ZEU}$ $\left(\mathrm{ZnSO}_{4}\right)$ application gave much higher economic return than $2.0 \%$ ZEU ( $\mathrm{ZnO})$. Experiment was conducted by Ramaprasad et al., (2011) on clay loam soil in farmer's field of Cheluvanuppalapadu village, Nagulappalapadu Mandal, Prakasam (Dt.), Andhra Pradesh during rabi 2007-08 to study the effect of soil and foliar application of Zinc sulphate on seed yield nutrient uptake and economics of kabuli chickpea ( $\mathrm{Cv}$ LBeG-7). It was reported that application of $25 \mathrm{Kg}$ $\mathrm{ZnSO} 4 /$ ha through soil in combination with $0.5 \% \mathrm{ZnSO} 4$ foliar spray twice (at 45 and 55 DAS) recorded highest $\mathrm{B}: \mathrm{C}$ ratio 1: 2.98 and 
net returns (Rs. 59,037 per hectare). Studies was conducted by Shivay et al., (2014) at IARI, New Delhi, on effect of Zinc application on yield, profitability, protein content and Zinc uptake by Chickpea, to assess the economic feaseability of the Zinc application over control treatments and found that there was significant enhancement of gross and net returns over control by way of increasing seed yield of chickpea crop. The study also revealed that benefit: cost ratio as well as net profitability of $\mathrm{Zn}$ applied treatments was also high over control treatments. Ghasal et al., (2015) reported a strong positive correlation between yield attributes (effective tillers/hill, fertility percentage and grains/panicle) and yield of rice. For net returns and benefit: cost ratio viewpoint, application of $2.5 \mathrm{~kg} \mathrm{Zn} / \mathrm{ha}$ $\left(\mathrm{ZnSO}_{4} .7 \mathrm{H}_{2} \mathrm{O}\right)+0.5 \%$ FS at maximum tillering and panicle initiation proved better and gave the highest net returns.

A field experiment was conducted by Jat et al., (2015) during Rabi 2010-11 at farmers' fields in Raniwas village of Dausa district of Rajasthan, which falls in agroclimatic zone IIIa (Semi arid eastern plain zone) and it was reported that the highest gross returns (Rs 35420/ha), Net returns (Rs 15238/ha) and B:C ratio (1.75) were recorded with the treatment T4 (500 ppm thiourea+ $0.2 \%$ zinc sulphate (mixed solution) spray at vegetative and reproductive stage) while in Treatment $\mathrm{T} 1$ (control) the gross returns (Rs 28420/ha), net returns (Rs 12020/ha) and B:C ratio (1.73) were recorded. Kumar et al., (2015) conducted a field experiment at Varanasi during the 2 consecutive pre-kharif (rainy) season of 2012 and 2013 on baby corn with three zinc levels $(0,5$ and $10 \mathrm{~kg} \mathrm{Zn} / \mathrm{ha})$ and observed that 5 and $10 \mathrm{~kg} \mathrm{Zn/ha}$ though remained comparable registered significantly higher net returns and benefit: cost ratio over the control. Singh and Shivay (2015) further observed that application of EDTA-chelated
Zn (12\% Zn) gave highest gross returns (US $\$ 1,713.68$ and US \$2,018.30/ha), but significantly lower net returns (US $\$ 782.77$ and US \$995.58/ha) compared to other $\mathrm{Zn}$ sources during 2009 and 2010, respectively.

The highest values of net returns were obtained by $\mathrm{ZnSO}_{4} .7 \mathrm{H}_{2} \mathrm{O} \quad(21 \% \quad \mathrm{Zn})$ application (US \$1,068.96 and US \$1, 250.22/ha), which was significantly higher than all other $\mathrm{Zn}$ sources, resulting into a higher net $\mathrm{B}: \mathrm{C}$ ratio of 1.88 and 1.89 during both years, respectively. Singh et al., (2015a) conducted the field experiment at research farm, Raja Balwant Singh College, Bichpuri, Agra, Uttar Pradesh by 4 levels of $\mathrm{K}_{2} \mathrm{O}$ and 4 levels of $\mathrm{Zn}(0,3.0,6.0$ and $9.0 \mathrm{~kg} / \mathrm{ha})$ in factorial experiment laid out in randomized complete-block design. They found that application perspective, the maximum net returns (49000.1 Rs/ha) and benefit: cost ratios (1.97) were obtained with $9 \mathrm{~kg} \mathrm{Zn} / \mathrm{ha}$ which was statistically non- significant with 6 $\mathrm{kg} \mathrm{Zn/ha.} \mathrm{No} \mathrm{Zn}$ treatment resulted in the lowest net returns and benefit: cost ratio due to lower grain and straw production.

To study the effect of moisture conservation and zinc fertilization on quality, nutrient uptake, profitability and moisture use indices of chickpea under limited moisture conditions, a field experiment was conducted by Choudhary et al., (2016), during rabi seasons of 2012-13 and 2013-14. It was reported that under zinc fertilization, direct application of $5.0 \mathrm{~kg} \mathrm{Zn/ha} \mathrm{significantly}$ improved the net returns and production efficiency during both the years of investigation over lower levels. Conducted experiment by Balai et al., (2017), at Agronomy farm, College of Agriculture, Bikaner during Rabi, 2009-10 reported that the application of $6 \mathrm{~kg} \mathrm{Zn/ha} \mathrm{recorded} \mathrm{higher}$ net returns (Rs. 21810.83 /ha) and higher B:C ratio (2.62). 


\section{Effect of Iron fertilization on}

\section{Effect of Iron fertilization on growth parameters}

\section{Effect of iron fertilization on the plant height of chickpea cultivars}

Mahriya and Meena (1999) while working on cowpea, at Jobner (Rajasthan), concluded that growth characters of plant like plant height were increased with the application of $\mathrm{Fe}$ foliar application over control treatments. Field experimentation conducted by Balachander et al., (2003) to study the effect of micronutrients on yield of gram reported that the application of $\mathrm{Fe}$ through ferrous sulphate significantly increased the plant height of chickpea over control. Experiments on chickpea were carried out by Gizawy et al., (2004), during the two winter seasons of 2001/02 and 2002/03 at the Experimental Center, Faculty of Agriculture at Moshtohor, Zagazig University and it was reported that spraying chickpea plants with Fe surpassed the tap water (control) in plant height of chickpea over rest of the treatments. Fasaei et al., (2013) conducted a greenhouse experiment to study the effect of iron treatments on the growth and nutrient composition of chickpea and reported that application of iron significantly increased plant height of chickpea plant over control.

\section{Effect of iron fertilization on the leaf area index of chickpea cultivars}

Mevada et al., (2005) reported improvement in the growth parameters like leaf area index by the application of $1.0 \mathrm{~kg}$ chelated iron/ha along with RDF over the $2.0 \mathrm{~kg}$ chelated iron and control in pulse crop. A field experiment was carried out by Janmohammadi et al., (2012), to study the effect of micro-nutrient (iron) application on yield and yield component of chickpea under irrigated conditions during 2010 growing season at experimental farm of the University of Tabriz. The results showed that application of Fe has significant effect on leaf area index, so that the lowest leaf area was recorded for control plants. Experiment conducted by Fasaei et al., (2013), to study the effect of iron treatments on the growth and nutrient composition of chickpea, revealed that application of iron significantly increased leaf area index of chickpea plant over control. A field experiment was conducted by Jha et al., (2015), at the instructional farm of Rajasthan College of Agriculture, Udaipur, Rajasthan during kharif season of 2013 to study the effect of organic and inorganic sources of nutrients on yield and economics of blackgram. The result indicated that application of $100 \% \mathrm{RDF}+\mathrm{Zn}+\mathrm{Fe}(\mathrm{N}: \mathrm{P}: \mathrm{K}-$ 20:30:15 kg/ha $+\mathrm{ZnSO}_{4} 5 \mathrm{~kg} / \mathrm{ha}+\mathrm{FeSO}_{4} 5$ $\mathrm{kg} / \mathrm{ha}$ ) recorded significantly highest leaf area index respectively over rest of the treatments.

Effect of iron fertilization on the dry matter accumulation of chickpea cultivars

Balachander et al., (2003) while studying the effect of micronutrients on yield of gram reported that the application of $\mathrm{Fe}$ through ferrous sulphate significantly increased the dry matter production of chickpea over control. Studies on chickpea were carried out by Gizawy et al., (2004), during the two winter seasons of 2001/02 and 2002/03 at the Experimental Center, Faculty of Agriculture at Moshtohor, Zagazig Universityand it was reported that spraying chickpea plants with $\mathrm{Fe}$ resulted in increased dry matter production as compared to the plants treated with no Fe. Singh et al., (1998) working on mungbean under clay laoms soils of Kanpur found that the dry matter accumulation was significantly increased with ferrous sulphate application. Mahriya and Meena (1999) while working on cowpea, at Jobner (Rajasthan), concluded that growth characters of plant like dry matter 
accumulation were increased with the application of Fe. Balachander et al., (2003) while studying the effect of micronutrients on yield of gram reported that the application of $\mathrm{Fe}$ through ferrous sulphate significantly increased the dry matter production of chickpea over control.

Studies on chickpea were carried out by Gizawy et al., (2004), during the two winter seasons of 2001/02 and 2002/03 at the Experimental Center, Faculty of Agriculture at Moshtohor, Zagazig University and it was reported that spraying chickpea plants with Fe resulted in increased dry matter production as compared to the plants treated with no Fe.

\section{Effect of Iron fertilization on Physiological parameters}

Khan et al., (2014) conducted field experiments to study the influence of different levels of Iron on the nodulation, nitrogen fixation and yield of chickpea genotypes, at Malakandher farm, University of Agriculture, Peshawar. The data pertaining to days to flowering showed that maximum number of days (138 days) for flowering were recorded in control, while the minimum numbers of days to flowering (133 days) were recorded where $\mathrm{Fe} 2 \mathrm{~kg} / \mathrm{ha}$ were apllied in both genotypes of chickpea.

A field experiment was conducted by Tayade et al., (2016), at Horticulture Section, College of Agriculture, Nagpur (Maharashtra) India, during 2010-2011.

The results of the experiment showed significant differences in growth, flowering, yield and quality parameters of annual chrysanthemum due to application of zinc and iron. It was found that days to $50 \%$ flowering were recorded significantly higher with application of $0.3 \%$ zinc and $0.3 \%$ iron.
Effect of zinc and iron fertilization on the yield and yield attributes of chickpea cultivars

Duraisamy et al., (2001) revealed that the combined application of $0.5 \%$ FeSO4 and $0.10 \% \quad \mathrm{MoO}_{4}$ recorded higher grain and haulms yield of 634 and $934 \mathrm{~kg} / \mathrm{ha}$ over control (467 and $745 \mathrm{~kg} / \mathrm{ha}$ ) in pulse crops under red loamy sandy soil. Reddy et al., (2007) reported that the application of chelated iron at $3.0 \mathrm{~kg} / \mathrm{ha}$ along with $\mathrm{RDF}$ was recorded higher grain yield of 2.2 tones/ha over the control (1.9 tones/ha) followed by 2.1 tones/ha by application of 2.0 $\mathrm{kg} / \mathrm{ha}$ in legumes under rainfed conditions in Vertisols of Andhra Pradesh. Umamaheswari et al., (2002) reported that there is increase in the pods/plant, seeds/pod and 100 seed weight in pulse crop by increasing level of application of ferrous sulphate from 2.5 to 5 $\mathrm{kg} / \mathrm{ha}$ under sandy loam soils of Varanasi. Balachander et al., (2003) while studying the effect of micronutrients on yield of gram reported that the application of $\mathrm{Fe}$ through ferrous sulphate significantly increased the grain yield of chickpea over control. Experiments on chickpea were carried out by Gizawy et al., (2004), during the two winter seasons of 2001/02 and 2002/03 at the Experimental Center, Faculty of Agriculture at Moshtohor, Zagazig University and it was reported that Spraying chickpea plants with $\mathrm{Fe}$ surpassed the tap water (control) in number of seeds/plant, weight of pods/plant, seed index, seed yield/plant, seed, straw and biological yield. Salam et al., (2004) reported that there is increase in the pods/plant, seeds/pod, seed/plant, pod weight/plant and seed weight/plant in legumes by increasing level of application of ferrous sulphate from 1.0 to $2.0 \mathrm{~kg} / \mathrm{ha}$ along with NPKS (20:50:20:20 kg/ha). Mevada et al., (2005) reported improvement in the growth parameters by the application of $1.0 \mathrm{~kg}$ chelated iron/ha along with RDF over the 2.0 
$\mathrm{kg}$ chelated iron and control in pulse crop. Ashoka et al., (2008) reported that the application of $25 \mathrm{~kg} \mathrm{ZnSO} 4+10 \mathrm{~kg} \mathrm{FeSO}_{4}+$ $35 \mathrm{~kg} \mathrm{FYM} / \mathrm{ha}$ along with RDF recorded higher grain yield of $14.34 \mathrm{q} / \mathrm{ha}$ over the control $(8.61 \mathrm{q} / \mathrm{ha})$ in chickpea in Vertisols of Karnataka. Conducted field experiments by Patel et al., (2008), during kharif seasons of 2002, 2003 and 2005 to study the effect of zinc and iron on yield and yield attributes of rainfed pulses at Main Pulses Research Station, S.D. Agricultural University, Sardarkrushinagar on loamy sand soil. It was reported that spraying of $0.5 \% \mathrm{FeSO}_{4}$ and $0.5 \% \mathrm{ZnSO}_{4}$ at $25 \mathrm{DAS}$ gave significantly higher straw yield of cowpea over control, $0.5 \% \mathrm{FeSO}_{4}$ spray at $25 \mathrm{DAS}$ and $0.5 \%$ $\mathrm{FeSO}_{4}$ spray at 45 DAS but was at par with the remaining treatments. Kumar et al., (2009) conducted an experiment at Kanpur and reported that the branches per plant, number of pods per plant, number of grains per pod and test weight significantly increased with levels of $\mathrm{Fe}$ upto $10 \mathrm{~kg} / \mathrm{ha}$ and enhanced the grain yield of chickpea by $17.3 \%$ over control. Similar trend in straw yield response was also recorded. Patel et al., (2009) reported that the combined spraying of $0.5 \% \mathrm{FeSO}_{4}$ and $0.5 \% \mathrm{ZnSO}_{4}$ spray at 25 and 45 DAS gave significantly higher seed and straw yield of pulse crop (1404 and 1975 $\mathrm{kg} / \mathrm{ha}$ ) over control. Gupta et al., (2012) reported that the application of $2.0 \mathrm{~g}$ ammonium molybdate $+1.0 \mathrm{~g}$ FeSO $4 / \mathrm{kg}$ seed treatment + Rhiizobium + PSB along with $\mathrm{RDF}$ recorded higher plant height $(40.32 \mathrm{~cm})$, branches/plant (5.86) and plant dry weight/plant at 90 DAS $(5.83 \mathrm{~g})$ over the control in chickpea under medium black Vertisol. A field experiment was carried out by Janmohammadi et al., (2012), to study the effect of micro-nutrient (iron) application on yield and yield component of chickpea under irrigated conditions during 2010 growing season at experimental farm of the university of Tabriz. The results showed that application of Fe has significant effect on plant height, so that the lowest height was recorded for control plants. Number of primary and secondary branches per plant also increased with application of the Iron application. Khan et al., (2014) conducted field experiment during 2011-12 at Malakandhar Farm, University of Agriculture, Peshawar, to study the influence of different levels of Iron on the yield of chickpea genotypes and the results showed that maximum yield and yield parameters were observed in those treatment plots where Fe $2.0 \mathrm{~kg} / \mathrm{ha}$ were applied. It was also reported that maximum shoot biomass $6434 \mathrm{~kg} / \mathrm{ha}$ were found in treatment plot where $\mathrm{Fe} 2 \mathrm{~kg} / \mathrm{ha}$ were applied while the minimum shoot biomass 4375 were recorded in control (where no $\mathrm{Fe}$ were applied). It showed that $\mathrm{Fe}$ application had positive effect on the production of shoot biomass. Also, the maximum grain yield of $465 \mathrm{~kg} / \mathrm{ha}$ were obtained for treatment receiving $\mathrm{Fe} 2.0 \mathrm{~kg} / \mathrm{ha}$, while minimum grain yield of $370 \mathrm{~kg} / \mathrm{ha}$ were obtained in control. Pingoliya et al., (2014) studied the effect of iron $(\mathrm{Fe})$ on growth and yield attributes of chickpea (Cicer arietinum L.) was studied during rabi season of 20102011 with $\mathrm{Fe}$ (control, 2.5, 5 and $7.5 \mathrm{~kg}$ $\mathrm{Fe} / \mathrm{ha}$ ) and it was found that with $5 \mathrm{~kg} \mathrm{Fe} / \mathrm{ha}$ plot, yield attributes like plant height, branch/plant, pods/plant, seed/pod and test weight were significantly improved compared to rest of the treatments. It was also observed that the increasing levels of iron up to $5.0 \mathrm{~kg}$ $\mathrm{Fe} /$ ha increased the plant height significantly. However, maximum plant height $(51.53 \mathrm{~cm})$ at harvest was recorded with the application of $7.5 \mathrm{~kg} \mathrm{Fe} / \mathrm{ha}$ but found at par with $5.0 \mathrm{~kg}$ $\mathrm{Fe} / \mathrm{ha}$. The application of $2.5,5.0$ and $7.5 \mathrm{~kg}$ $\mathrm{Fe} /$ ha significantly increased the plant height to the tune of $2.3,12.11$ and 19.15 per cent, respectively over control $(43.33 \mathrm{~cm})$. Application of $5.0 \mathrm{~kg} \mathrm{Fe} / \mathrm{ha}$ significantly increased seed yield over control and $2.5 \mathrm{~kg}$ $\mathrm{Fe} / \mathrm{ha}$ by 30.19 and 19.17 per cent, respectively. Fasaei et al., (2015) conducted a 
greenhouse experiment to study the effect of iron and zinc treatments on the growth and nutrient composition of chickpea and reported that application of Iron significantly increased mean Fe concentration in chickpea plant and also concluded that the use of $\mathrm{Fe}$ and $\mathrm{Zn}$ efficient genotypes should be considered as an appropriate practice for chickpea grown on calcareous soils low in available Fe and Zn. A field experiment was conducted by Jha et al., (2015), at the instructional farm of Rajasthan College of Agriculture, Udaipur, Rajasthan during kharif season of 2013 to study the effect of organic and inorganic sources of nutrients on yield and economics of blackgram. The result indicated that application of $100 \% \mathrm{RDF}+\mathrm{Zn}+\mathrm{Fe}$ recorded significantly number of pods, number of seeds, seed yield, straw yield, biological yield, harvest index, respectively over rest of the treatments but it was at par with $100 \%$ RDF, 50\% RDF+50\% RDN through FYM and FYM 4 t/ha. The seed yield of gram significantly increased by 8.75 over $100 \%$ RDF.

\section{Effect of zinc fertilization on quality and uptake}

Kumpawat et al., (1994) while studying the effect of micronutrients on the protein content of gram reported that the application of $20 \mathrm{~kg}$ $\mathrm{FeSO}_{4} /$ ha significantly increased the dry weight of nodules, seed protein content and seed yield over control treatments. Shukla et al., (1994) from Allahabad, India while working on effect of $\mathrm{Fe}$ and $\mathrm{Zn}$ in Chickpea crop reported that application of 25 and $50 \mathrm{~kg}$ $\mathrm{FeSO}_{4}$ /ha to chickpea crop resulted in increased number of nodules per plant, dry weight of root nodules, leg haemoglobin content of root nodules and rate of $\mathrm{N}_{2}$ fixation as compared to control treatment that ultimately increased the growth and yield of Chickpea crop. It was also observed that increase in $\mathrm{Fe}$ concentration in seeds of Chickpea with increasing levels of $\mathrm{FeSO}_{4}$ up to $50 \mathrm{~kg} / \mathrm{ha}$ over control. Mahriya et al., (1999) conducted a field trail at Jobner (Rajasthan), and they concluded that all the growth characters as well as protein content in seed were increased with the application of 4 $\mathrm{kg} \mathrm{Fe} / \mathrm{ha}$. Duraisamy et al., (2001) reported that spraying of $0.5 \% \mathrm{FeSO} 4 /$ ha significantly increased the iron content in grain $(434 \mathrm{~g} / \mathrm{ha})$ and combined soil application of $10 \mathrm{~kg}$ $\mathrm{FeSO}_{4} / \mathrm{ha}$ and increased the iron content in haulms (624 g/ha) over the control in gram. Patel et al., (1993) conducted a field trail on calcareous soils of Gujarat revealed that foliar spray of one percent $\mathrm{FeSO}_{4}+0.1 \%$ citric acid significantly increased concentration of $\mathrm{Fe}$ in legume leaves by $160.78 \%$ at 60 days of crop over control. Gizawy et al., (2004) carried out two field experiments on chickpea during the two winter seasons of 2001/02 and 2002/03 at the Experimental Center, Faculty of Agriculture at Moshtohor, Zagazig University and it was observed that spraying chickpea plants with Fe increases the protein yields and seed P content. Kumawat et al., (2006) observed that the application of $25 \mathrm{~kg}$ $\mathrm{FeSO}_{4} / \mathrm{ha}$ in pulse crop increased the activities of the catalase, guaiacol peroxidase synthesis of chlorophyll and active Fe content of green leaves over lower doses of $\mathrm{FeSO}_{4}$ and controlled treatment. Sahu et al., (2008) also reported that the application of $\mathrm{FeSO}_{4}$ at the rate of $2 \mathrm{~kg} / \mathrm{ha}$ significantly increased the protein content of the seed and also the grain yield of Chickpea crop. This might be due to increased nitrogenase activities and more nitrogen fixation at lower doses. Study was carried out by Janmohammadi et al., (2012) during 2010 growing season at experimental farm of the university of Tabriz, to study the effect of bio-fertilizer and micro-nutrients (iron and zinc) application on yield and yield component of chickpea under irrigated conditions, where it was found that positive effects of micro-nutrients application on morphological traits were more predominant than bio-fertilizer inoculation. It was also 
observed that the highest chlorophyll index was recorded in plants that had been received $\mathrm{Fe}$, as their chlorophyll index was $26 \%$ higher over control. Conducted field experiment by Khan et al., (2014), during 2011-12 at Malakandhar Farm, University of Agriculture, Peshawar, to study the effect of Iron on nodulation and nitrogen fixation of Chickpea genotypes reported that with increasing levels of $\mathrm{Fe}$ in soil, the concentration of $\mathrm{Fe}$ in plant leaves significantly increased at flowering stage. Moreover, the study revealed that application of $\mathrm{Fe} 2.0 \mathrm{~kg} / \mathrm{ha}$ is important which plays a significant role in getting the maximum nodules and nitrogen concentration in chickpea genotypes. It was observed that the maximum iron concentration was obtained for the treatment receiving $\mathrm{Fe} 2.0 \mathrm{~kg} / \mathrm{ha}$ which is $276 \mu \mathrm{g} / \mathrm{g}$ over control treatments. Results showed that increased concentration of Iron in plants may be due to the positive interaction within legume plants. Field experiment was conducted by Pingoliya et al., (2015), to see the effect of phosphorus $(\mathrm{P})$ and iron $(\mathrm{Fe})$ on protein content in grain and chlorophyll content in leaf of chickpea (Cicer arietinum L.). The study revealed that application of $\mathrm{Fe}$ also increased the protein content with increasing level from 0 to $7.5 \mathrm{~kg} \mathrm{Fe} / \mathrm{ha}$. It was lower $(23.45 \%)$ in control and higher in highest level, which was at par with $5 \mathrm{~kg}$ $\mathrm{Fe} / \mathrm{ha}$. In the chlorophyll content maximum increased was observed in $7.5 \mathrm{~kg} \mathrm{Fe} /$ ha over $0,2.5$ and $5 \mathrm{~kg} \mathrm{Fe} / \mathrm{ha}$. It was observed that Iron application at 2.5 and $5 \mathrm{~kg} \mathrm{Fe} / \mathrm{ha}$ significantly increased the protein content to the tune of 8.07 and 18.58 per cent, respectively over control (19.69 per cent) but are found at par with $7.5 \mathrm{~kg} \mathrm{Fe} / \mathrm{ha}$. However, maximum protein content in grain was found at the level of $7.5 \mathrm{~kg} \mathrm{Fe} / \mathrm{ha}$. The result also observed that application of $7.5 \mathrm{~kg} \mathrm{Fe} / \mathrm{ha}$ significantly increased the chlorophyll content in leaf to the extent of $6.75,5.85$ and 4.97 per cent, respectively over control, 2.5 and $5 \mathrm{~kg}$
$\mathrm{Fe} / \mathrm{ha}$. Conducted field experiment by Singh et al., (2015), during two consecutive rabi seasons of 2012-13 and 2013-14 at New Research Farm, ICAR-Indian Institute of Pulses Research, Kanpur, Uttar Pradesh, to study the effect of diverse combinations of foliar fertilization on growth, yield attributes, yield, nutrient partitioning and nutritional enrichment of chickpea reported that foliar spray with iron significantly enhanced concentration of protein, zinc and iron, respectively over no spray. It was observed that iron spray enhanced iron concentration in chickpea grain by 21.9 per cent, respectively. It was also found that application of iron foliarly might helped in better photosynthesis and photosynthate partitioning to yield attributing characters which resulted in higher sink size (Ferrandon and Chamel, 1988; Ghasemi- Fasaei et al., 2005; Shivay et al., 2013). Khalid et al., (2015) conducted a pot study in University of Agriculture, Faisalabad, Pakistan, to determine the effect of bio fortification of iron in chickpea and it was observed that application of $\mathrm{FeSO}_{4}$ significantly improved the $\mathrm{Fe}$ content upto 100 and $173 \%$ in grain and shoot respectively, as compared to control.

\section{Effect of Iron fertilization on Relative Economics}

Field experiments were conducted by Anitha et al., (2005), under AICRP on Arid Legumes during kharif seasons 2001- 2002 to elucidate the response of pulses to zinc and iron fertilization for augmenting the crop productivity. It was observed that combined spraying of $0.5 \% \mathrm{FeSO}_{4}$ and $0.5 \% \mathrm{ZnSO}_{4}$ at 45 DAS proved most effective and increased the seed yield by 43.09 per cent when compared with control followed by combined spraying of $0.5 \% \mathrm{FeSO}_{4}$ and $0.5 \% \mathrm{Znso}_{4}$ at $25 \mathrm{DAS}$ (40.14\%). The net return and benefit cost ratio also followed the same trend. A field experiment was conducted by Patel et al., 
(2008), during kharif seasons of 2002, 2003 and 2005 to study the effect of zinc and iron on yield and yield attributes of rainfed pulses at Main Pulses Research Station, S.D. Agricultural University, Sardarkrushinagar on loamy sand soil. The results revealed the the highest net return of Rs.13, 114 per ha was obtained when the crop was fertilized with soil application of $25 \mathrm{~kg} \mathrm{ZnSO}_{4}$ per ha followed by the foliar spray of $0.5 \% \mathrm{FeSO}_{4}$ and $0.5 \% \mathrm{ZnSO}_{4}$ at 25 DAS (Rs. 11,038/ha) and $0.5 \% \mathrm{ZnSO}_{4}$ at 25 and 45 DAS (Rs. 10,978/ha). Field experiment conducted by Singh et al., (2014), at the Punjab Agricultural University, Ludhiana, during the rainy (kharif) season of 2010 and 2011 with 13 treatments in randomized block design, to determine the effect of foliar feeding of micronutrients on growth and yield of directseeded basmati rice (Oryza sativa L.). The result showed that 4 sprays of $1.0 \%$ solution of $\mathrm{FeSO}_{4}$ at 40, 50, 60 and 70 days after sowing DAS gave higher net returns and benefit: cost ratio over the control. Conducted field experiments by Jha et al., (2015), at the instructional farm of Rajasthan College of Agriculture, Udaipur, Rajasthan during kharif season of 2013 to study the effect of organic and inorganic sources of nutrients on yield and economics of gram. The result indicated that application of $100 \% \mathrm{RDF}+\mathrm{Zn}+\mathrm{Fe}$ $\left(\mathrm{N}: \mathrm{P}: \mathrm{K}-20: 30: 15 \mathrm{~kg} / \mathrm{ha}+\mathrm{ZnSO}_{4} 5 \mathrm{~kg} / \mathrm{ha}+\right.$ FeSO45 kg/ha) recorded significantly gross return, net return and $\mathrm{B}$ : $\mathrm{C}$ ratio, respectively over rest of the treatments. Application of $100 \% \mathrm{RDF}+\mathrm{Zn}+\mathrm{Fe}$ and $100 \% \mathrm{RDF}$ significantly increased the net return and benefit cost ratio of gram over control. The net return of gram significantly increased by 11.22 per cent, respectively over $100 \%$ RDF. Lashkari et al., (2008) found that the cultivation of cauliflower cv. SNOWBALL16 was found to be more beneficial and economical with foliar sprays of Zinc $\left(\mathrm{ZnSO}_{4}\right)$ and Iron $\left(\mathrm{FeSO}_{4}\right)$ in nine treatment combinations considering 3 levels of $\mathrm{Zn}(0.0$,
0.5 and $1.0 \%)$ and 3 levels of Fe $(0.0,0.5$ and $1.0 \%$ ) during rabi season of the year, 200203. Significantly highest marketable yield with highest net return was obtained with combine foliar sprays of zinc and iron at $0.5 \%$ concentration each.

In conclusion the study conducted for demonstrating the review of literature of last three decades in front of the scientists of across the globe clearly indicated that Unlike plants, humans also require essential micronutrients and protein for normal physiological functions of the body and general health. Due to low concentration of micronutrients and protein in the staple food, billions of population is lacking sufficient daily intake of micronutrient and protein in their diet sometimes called 'hidden hunger'. Micro nutrient malnutrition is a serious problem to human health throughout the world, primarily in resource limited countries. The micronutrients most commonly associated with human health problems on a global scale include iron, zinc and iodine. Humans require at least 22 mineral elements for their wellbeing. These can be supplied by an appropriate diet. However, it is estimated that over 30 percent of population is zinc $(\mathrm{Zn})$ deficient and rest with other micronutrients. Among micronutrients, $\mathrm{Zn}$ deficiency is occurring in both crops and humans. Zinc deficiency is currently listed as a major risk factor for human health and cause of death globally. According to an estimate of World Health Organization (WHO) during 2015, around two billion people are being suffered with iron and zinc deficiencies and its deficiency ranks $11^{\text {th }}$ among the 20 most important factors in the world and $5^{\text {th }}$ among the 10 most important factors in developing countries like India. $\mathrm{Zn}$ deficiency is widespread in chickpea growing region of the world and is most prevalent among the micronutrients. In the sequence of micronutrient malnutrition; iron is also 
playing a vital role. The agronomic biofortification of zinc and iron in chickpea under rainfed areas for poor and under nourished masses of south East Asia is an important and easy tool to fight against the nutritional security.

\section{References}

Akay, A. 2011.Effect of zinc fertilizer applications on yield and element contents of some registered chickpeas varieties. African Journal of Biotechnology, 10(60): 12890-12896.

Alam, M. N., Adedin, M. J. and Azad. M. A. K. 2010. Effect of micronutrients on growth and yield of onion under calcareous soil environment. International research Journal of Plant Science, 1(3):056-061.

Alam, M. A. and Kumar, M. 2015. Effect of zinc on growth and yield of rice var. Pusa Basmati-1 in Saran district of Bihar. Asian Journal of Plant Science and Research, 5(2): 82-85.

Anitha, S., Sreenivasan, E. and Purushothaman, S. M. 2005. Response of cowpea (Vigna unguiculata) to foliar nutrition of zinc and iron in the oxisols of kerala.Legume Research, 28(4): 294 - 296.

Anon. 2009. Agricultural statistics at a glance. Ministry of Agriculture, New Delhi.

Anonymous, 2015. Ferti-fortification: an easy approach for nutritional enrichment of chickpea. Indian Institute of Pulses Research, Kanpur.pp1.

Anonymous, 2011-12. FAOSTAT. Food and Agriculture organization of the United Nations. http://faostat.fao.org.

Anonymous, 2012-13. Annual Report, Department of Agriculture and Cooperation and farmers Welfare, Ministry of Agriculture and Farmers Welfare, Government of India, Krishi Bhawan, New Delhi. Pp. 1.

Ashoka, P., Pujari, B. T. M., Hugar, P. S. and Desai, B. K. 2008. Effect of micronutrients with or without organic manures on yield of baby corn (Zea mays L.-Chickpea (Cicer artietinum L.) sequence. Karnataka Journal of Agricultural Sciences, 21(4):485-487.

Auld, D.S. 2001. Zinc coordination sphere in biochemical zinc sites. Biometals, 14:271313.

Balachandar, D., Nagarajan, P. and Gunasekaran. S. 2003. Effect of organic amendments and micronutrients on Nodulation and yield of black gram in acid soil. Legumes Research, 26:192-195.

Balai, K., Sharma, Y., Jajoria, M., Deewan, P. and Verma. R. 2017. Effect of Phosphorus, and Zinc on Growth, Yield and Economics of Chickpea (Cicer aritinum L.). International Journal of Current Microbiology and Applied Sciences, 6(3):1174-1181.

Bates, L.S., Waldren, R.P. and Teare, I. D. 1973.Rapid determination of free proline for water stress studies. Plant Soil, 39:205-207.

Benoist, B.D., Mclean, E., Andersson, M. and Rogers. L. 2008. Iodine deficiency in 2007: Global progress since 2003. Food Nutrition Bulletin, 9(3):195-202.

Best, C.,Neufingerl, N., Rosso, J. M. D., Transler, C, Briel, T. D. and Osendarp. S. 2011. Can multi micronutrient food fortification improve the micronutrient status, growth, health, and cognition of schoolchildren? A systematic review. Nutrition Reviews, 69(4): 186-204.

Baghel, J. K., Singh, Y. V., Kumar, D., Abraham, G. and Singh. S. 2013. Effect of varieties and nitrogen management on nematodes infestation and productivity of aerobic rice. Indian Journal of Agronomy, 58(3):427-429.

Black, C. A., Evans, D. D., White, J. L., Ensminger, L. E. and Clark, F. E. 1965.Methods of Soil Analysis.Part 1, Agronomy No. 9. American Society of Agronomy, 770 pp.

Brennan, R. F., Bolland, M. D. A and Siddique. K. H. M. 2001. Responses of cool-season grain legumes and wheat to soil-applied zinc. Journal of Plant Nutrition. 24(4-5): 727-741.

CRIDA, 2007. Vision-2025: CRIDA 
perspective plan, Central Research Institute for Dryland Agriculture, Hyderabad.

Choudhary, G. L., Rana, K. S., Bana, R. S., and Prajapat. K. 2016. Moisture conservation and zinc fertilization impacts on quality, profitability and moisture use indices of chickpea (Cicer arietinum L.) under limited moisture conditions. Legume Research, 39(5):734-740.

Cokkizgin, A. 2012. Botanical Characteristics of Chickpea Genotypes (Cicer arietinum L.) Under Different Plant Densities in Organic Farming. Scientific Research and Essays. Academic Journal, 7(4):498-503.

Dadkhah, N., Ebadi, A.,Parmoon, G. H.,Ghlipoori G.H., Jahanbakhsh. S. 2015. The effects of zice fertilizer on some physiological characteristics of chickpea (Cicer arietinum L.) under water stress. Iranian Journal of Pulses Research, 6(2): 59-72.

Duraisamy, P. and Mani. A. K. 2001. Effect of iron and molybdenum on yield and nutrition of horse gram in red loamy sand soil. Mysore journal of Agricultural Science, 35: 26-31.

El- Tohamy, W. A., Khalid, H.M, El- Abagy and S. D. Abou-Hussein. 2009. Essential oil, growth and yield of onion (Allium сера L.) in response of foliar application of some micronutrients. Australian Journal Basic and Applied Science, 3(1): 201-205.

Enania, A. R. and Vyas. A. K. 1994, Effect of phosphorus and zinc application on growth, biomass and nutrient uptake by chickpea in calcareous soil. Annals of Agricultural Research., 15(4): 397-399.

FAOSTAT, 2013. Food and Agricultural Organization, Statistics Division, Online Interactive Database on Agriculture (Website: http://www.faostat.fao.org/).

FAO, 2015.World Agriculture: Towards 2015/2030, Summary Report, Food and Agriculture Organization, Rome.

Fasaei, R.G. and Ronaghi, A. 2015. The influence of Iron chelate and Zinc sulfate on the growth and nutrient composition of chickpea grown on a calcareous soil. Iran Agricultural Research, 34(2):35-40.

Ghasal, P. C., Shivay, Y. S. and Pooniya, V. 2015. Response of basmati rice (Oryza sativa) varieties to zinc fertilization. Indian Journal of Agronomy, 60(3):403409.

Gizawy, N. and Mehasen, S. A. S. 2004. Yield and seed quality responses of chickpea to inoculation with phosphorein, phosphourus fertilizer and spraying with iron. The 4th Scientific Conference of Agricultural Sciences, Assiut, December, 2004.

Gowda, K. M., Halepyati, A. S., Koppalkar, B. G. and Rao, S. 2014. Response of pigeonpea (Cajanus cajan L.) to application of micronutrients through soil and foliar spray of macronutrients on yield, economics and protein content. Karnataka Journal of Agricultural Science, 27(4):(460-463).

Graham, R.D., Welch, R.M., Saunders, D.A., Monasterio, I., Bouis, H.E., Bonierbale, S. de Hann., Burgos, G., Thiele, G., Liara, R., Meisner, C.A., Beebe, S.E., Potts, M.J., Kadiajn, M., Hobbs, P.K., Gupta, R.K and Twomlow. S. 2007. Nutritious subsistence food systems. Advances in Agronomy, 92:1-74.

Habbbasha, S.F., Mohamed, M.H., Abd ElLAteef, E.M., Mekki, B.B. and Ibrahim. M.E. 2013. Effect of combined Zinc and Nitrogen on Yield, chemical constituents and Nitrogen Use efficiency of some chickpea cultivars under sandy soil conditions. World Journal of Agricultural Sciences, 9(4): 354-360.

Hadi, M.R.H.S., Bazargani, P. and Darzi.M.T. 2013. Effects of Irrigation treatments and Zinc foilar Application on yield and yield components of Chickpea (Cicer aeritinum).International Journal of Farming and Allied Sciences, 2(19): 720724.

Hidoto, L., Worku, W., Mohammed, H. and Taran. B. 2017. Effects of zinc application strategy on zinc content and productivity of chickpea grown under zinc deficient 
soils. Journal of Soil Science and Plant Nutrition, 17(1):112-126.

Hossain, M. D., Hasan, M., Sultana, R. and Bari. A. K. M. 2016. Growth and yield response of chickpea to different levels of boron and zinc. Fundamental and Applied Agriculture, 1(2):82-86.

Hotz, C., Brown K. H. 2004. Assessment of the risk of $\mathrm{Zn}$ deficiency in population and options for its control. Food and Nutition Bulletin, 25:S91-S204.

Imsande, J. 1998. Iron, sulfate and chlorophyll deficiencies: A need for an integrative approach in plant physiology. Physiologia Plantarum, 103:139-144.

Ingle, S., Kuchanwar, O. D., Hirsat, P. S., Zalte, S. G. and Patangray. A. J. 2016. Effect of foliar application of zinc and iron on growth, yield and quality of gladiolus, 16(1):387-389.

Jackson, M. L. 1973. Soil chemical analysis. Asia Publication House, Bombay, pp 165167.

Janmohammadi, M. and Javanmard.A. 2012.Influences of micro-nutrients (zinc and iron) andbio-fertilizer on yield and yield components of chickpea (Cicer arietinum 1.) cultivars. Agriculture \& Forestry, 57(11):53-66.

Jat, B. $\quad$ L., Gupta, J. K., Meena, R. L., Sharma, R. N. and Bhati. D. S. 2015. Effect of foliar application of zinc sulphate and thiourea on productivity and economics of chickpea (Cicer aritenum). Journal of Progressive Agriculture, $5(2): 62-65$.

Jha, D. P., Sharma, S. K. and Amarawat. T. 2015. Effect of organic and inorganic sources of nutrients on yield and economics of blackgram (Vigna mungoL.) grown during kharif. Agricultural Science Digest, 35(3):224-228.

Kayan, N., Gulmezoglu, N. and Kaya. M.D. 2015. The optimum foliar zinc source and level for improving $\mathrm{Zn}$ content in seed of chickpea. Legume Research, 38(6): 826831.

Kennedy, G., Nantel, G. and Sheety, P. 2003. The scourge of "hidden hunger": Global dimensions of micronutrient deficiencies.

Journal of Food Nutrition and Agriculture, 32:8-16.

Khalid, S., Asghar, H. N., Akhtar, M. J., Aslam, A.andZahir. Z. A. 2015. Biofortification of iron in chickpea by plant growth promoting rhizobacteria. Pakistan Journal of Botany, 47(3):1191-1194.

Khan, H.R., Donald, G. K.and Rengel, Z. 2003. $\mathrm{Zn}$ fertilization improves water use efficiency, grain yield and seed $\mathrm{Zn}$ content in chickpea. Plant and Soil, 249:389-400.

Khan, HR, McDonald, G.K. and Rengel.Z. 2004. Zinc fertilization and water stress affects plant water relations, stomatal conductance and osmotic adjustment in chickpea (Cicer arietinum). Plant and Soil, 267(1-2): 271-284.

Khan, N., Tariq, M., Ullah, K., Muhammad, D., Khan, I., Rahaullah, K., Ahmed, N. and Ahmed. S. 2014. The effect of molybdenum and iron on nodulation, nitrogen fixation and yield of chickpea genotypes (Cicer arietinum L). IOSR Journal of Agriculture and Veterinary Science, 7(1):63-79.

Kharol, S., Sharma, M., Purohit, H. S., Jain, H. K., Lal, M., Sumeriya. H. K. 2014. Effect of sulfur and zinc nutrition on yield, quality and nutrient content and uptake by chickpea (Cicerarietinum L.) under agroclimatic zone IVa of Rajasthan. Environment and Ecology, 32(4):14701474.

Kumar, V., Dwivediand VN., Tiwari, D.D. 2009. Effect of phosphorus and Iron on yield and mineral nutrition in chickpea. Annals ofPlant and soil Research, 11:1618.

Kumar, R., Bohra, J. S., Singh, A. K. and Kumawat.N. 2015. Productivity, profitability and nutrient-use efficiency of babycorn (Zea mays) as influenced of varying fertility levels. Indian Journal of Agronomy, 60(2): 285-290.

Kumpawat, B.S. and Manohar, S. 1994. Effect of Rhizobium inoculation, phosphorus and micronutrients on nodulation and 
Protein content of Gram. The Madras Agricultural Journal, 81:630-631.

Kumawat, R. N., Rathore, P. S. and Pareek. N. 2006. Response of mung bean to sulphur and iron nutrition grown on calcareous soil of western Rajasthan. Indian Journal of Pulse Research, 19:228-230.

Kushwaha. B. L. 1997.Contribution of micronutrients in increasing the productivity of different pulse crops. Proceeding III International Food Legume Conference, Adelaide Australia, 22-26th September.

Lashkari, C. O., Parekh, H. B., Sharma, S. J., Karetha, K. M. and Kakade. D. K. 2008. Beneficial effect of foliar spray of zinc and iron on economics of cauliflower cv.SNOWBALL-16.The Asian Journal of Horticulture, 3(2):422-424.

Lindsay, W.L. 1972. Zinc in soil and plant nutrition. Advances in Agriculture.24:147186.

Lindsay, W. L. and Norvell. W. A. 1978. Development of a DTPA soil test for zinc, iron, manganese and copper. Soil Science Society, American Journal, 42:421-428.

Mahriya, A.K. and Meena.N. L. 1999. Response of phosphorus and iron on growth and quality of cowpea (Vigna unguiculata L.). Annals of Agricultural Biology Research, 4: 203-205.

Marschner, H. (1995). Mineral Nutrition of Higher Plants. London, 889 pp.

Martre, P., Porter, J.R., Jameison, P.D. and Tribo. E. 2003. Modeling grain nitrogen accumulation and protein composition to understand the sink/source regulations of nitrogen remobilization for wheat. Plant Physiology, 133:1959-1967.

Mathews, D.V., Patil, P.L. and Dasog.G.S. 2006. Effect of nutrients and biofertilizers on nutrient uptake by rice and residual soil fertility status in coastal alluvial soil of Karnataka. Karnataka Journal of Agricultural Sciences, 19(4):793-798.

Mehdi, S. M., Ranjaa, A. M. and Hussain. T. 1990. Relative efficiency of various sources of zinc. Sharad Journal Agriculture, 6:103-106.
Mevada, K. D., Patel, J. J. and Patel. K. P. 2005. Effect of micronutrients on yield of urdbean. Indian Journal of Pulses Research, 18(2):214-216.

Naik, S.K. and Das, D.K. 2008.Relative performance of chelated zinc and zinc sulphate for lowland rice (Oryza sativa L.). Nutrient Cycling Agro-ecosystems, 81(3): 219-227.

Nandan, B., Sharma, B. C., Kumar, A. and Sharma. N. 2012. Profitability of mustardmaize intercropping sequences in changing environment scenario under kandiareas of Jammu region. Indian Journal of Agronomy, 523-24.

Naruka, I.S., Gujar, K.D. and L. Gopal. 2000. Effect of foliar application of Zinc and Molybdenum on growth and yield of okra (Abelmnoschus esculentus L. Moench) cv. Pusa Sawani. Haryana Journal of Horticultural Science, 29(3/4):266-267.

Olsen, S. R., Cole, C. V., Watanable, F. S. and Dean, L. A. 1954.Estimation of available phosphorus in soils by extracting with sodium bicarbonate. United State Department of Agriculture Circulation, pp 939.

Ozturk, L., Yazici, M. A., Yucel, C., Toron, A. and Cakmak. I. 2006. Concentration and localization of zinc during seed development and germination in wheat. Plant Physiology, 128:144-152.

Pandey, N., Gupta, B. and Pathak, G.C. 2013. Foliar application of $\mathrm{Zn}$ at flowering stage improves plant's performance, yield and yield attributes of black gram. Indian Journal of Experimental Biology, 51: 548555.

Paramesh, V., Dhar, S., Vyas, A. K. and Dass. A. 2014. Studies on impact of phosphoenriched compost, chemical fertilizer and method of zinc application on yield, uptake and quality of maize (Zea mays). Indian Journal of Agronomy, 59(4):613-618.

Parimala, K., Anitha, G. and Reddy. A.V. 2013. Effect of Nutrient Sprays on Yield and Seedling Quality Parameters of Chickpea (Cicer arietinum L.). Plant Archives, 
13(2):735-737.

Patel, M. M., Patel, I. C., Patel, P. H., Patel, A. G., Acharya, S. and Tikka. S. B. S. 2009.Impact of foliar nutrition of zinc and iron on the productivity of cowpea under rainfed condition. Journal of Arid Legumes, 6(1):49-51.

Patel, M. M., Patel, I. C., Patel, R. I. and Acharya. S. 2011. Effect of Zinc and Iron on Yield and Yield Attributes of Rainfed Cowpea (Vigna unguiculata L. Walp). Annals of Arid Zone, 50(1):17-19.

Pathak, G. C., Gupta, B. and Pandey. N. 2012. Improving reproductive efficiency of chickpea by foliar application of zinc. Brazilian Journal of Plant Physiology, 24(3):173-180.

Pingoliya, K. K., Dotaniya, M. L. and Lata.M. 2014. Effect of iron on yield, quality and nutrient uptake of chickpea (Cicer arietinum L.). African Journal of Agricultural Research, 9(37):2841-2845.

Pingoliya, K. K., Mathur, A. K., Dotaniya, M.L. and Dotaniya, C.K. 2015. Impact of phosphorus and iron on protein and chlorophyll content in chickpea (Cicer arietinum L.). Legume Research, 38(4):558-560.

Piper, C. S. 1966. Soil and Plant Analysis, Hans Publishers, Bombay.

Pooniya, V., Shivay, Y. S., Ranab, A., Nainb, L. and Prasanna. R. 2012. Enhancing soil nutrient dynamics and productivity of Basmati rice through residue incorporation and zinc fertilization. European Journal of Agronomy, 41:2837.

Prasad, R. 2009. Zinc Malnutrition and its alleviation through Zinc Fortified Cereal Grains. In The Proceeding of Indian National Science Academy, 75(2): 89-91.

Pradhan, A., Thakur, A. and Sonboir, H. L. 2014.Response of rice varieties to different levels of nitrogen under rainfed aerobic ecosystem. Indian Journal of Agronomy, 59(1): 76-79.

Ramprasad, P. D., Rao, C. P. and Srinivasulu. K. 2011. Effect of Zinc Management on Yield, Nutrient Uptake and Economics of
Kabuli Chickpea (Cicer kabulicem L). Department of Agronomy.

Rana, A., Joshi, M., Prasanna, R., Shivay, Y.S. and Nain. L. 2012. Biofortification of wheat through inoculation of plant growth promoting rhizobacteria and cyanobacteria. Journal of Soil Biology, 50:118-126.

Rasul, F., Cheema, M. A., Sattar.A., Saleem, M. F. and Wahid. M. A. 2012. Evaluating the Performance of Three Mungbean Varieties Grown under Varying Inter-row Spacing. Journal of Animal \& Plant Sciences, 22(4): 1030-1035.

Rathore, R.S., Singh, R.P. and Nawange, D.D. 2010. Effect of land configuration, seed rates and fertilizer doses on growth and yield of blackgram (Vigna mungo L.). Legume Research, 33:274-278.

Reddy, M. M., Padmaja, B., Malathi, S. and Rao, L.J. 2007.Effects of micronutrients on growth and yield of pigeonpea. Journal of SAT Agricultural Research, 5(1):1-3.

Roy, P. D., Narwal, R. P., Malik, R. S., Saha, B. N. and Kumar. S. 2013. Impact of zinc application method on green gram (Vigna radiata L.) productivity \& grain zinc fortification. Journal of Environmental Biology, 25(4):87-91.

Sahu, S., Lidder, R.S. and Singh. P. K. 2008. Effect of micronutrients and biofertilizers on growth, yield and nutrient uptake by chickpea (Cicer aeritinum L.) in Vertisols of Madhya Pardesh. Advances in Plant sciences, 21:501-503.

Sajid, M., Hussain, A., Rab, A., Shah, S.T. and Jan. I. 2016. Influence of zinc as soil and foliar application on growth and yield of okra (Abelmoschus esculentus L.), 2(2):140-145.

Sakal, R., Singh, R. B. and Singh, A. P. 1980. Effect of zinc and boron application on black gram and chickpea production in calcareous soil. Fertilizer News, 24:27-30.

Sakal, R., Sinha, R. B., Singh, A. P. and Bhogal. N. S. 1998. Response of some Rabi pulses to boron, zinc and sulphur application of farmer's field. Fertilizer 
News, 43 (1):39-40.

Salam, P. K., Rajput, R. S., Mishra, P. K., Anita and Shrivastava. G. K. 2004. Effect of micronutrients fertilization on productivity potential of urdbean (Phaseolus mungo L.). Annals of Agricultural Research. New Series, 25(2):329-332.

Sandhu, J. S., Singh, S., Bains, T. S., Singh, I., Gill, B.S., Gill, R. K., Kumar, A. and Dhaliwal. I. 2015. Progress in varietal development in Pulse crop. Annual group meet on Rabi Pulses. PAU, Ludhiana, pp.04-10.

Sangwan, P. S. and Raj. M. 2004. Effect of zinc nutrition on yield of chickpea (Cicer arietinum L.) under dryland conditions. Indian Journal of Dryland Agricultural Research \& Development, 19(1):01-03.

Shaban, M., Lak, M., Hamidvand, Y., Nabaty, E., Khodaei, F., Yarahmadi, M., Azimi, S. M., Rahmat, M. G., Shaban, M. and Motlagh. Z. R. 2012. Response of chickpea (Cicer arietinum L.) cultivars to integrated application of Zinc nutrient with water stress. International Journal of Agriculture and Crop Sciences, 4:10741082.

Shamsi, K. 2005. The Effects of Planting Density on Grain Filling, Yield and Yield Components of Three Chickpea (Cicer arietinum L.) Varieties in Kermanshah, Iran. Journal of Animal and Plant Sciences, 2(3):99-103.

Sheftela, A.D., A.B. Mason and P. Ponka. 2011. The long history of iron in the universe and in health and disease. Biochimica et BiophysicaActa (BBA) - General Subjects, 1820(3): 161-187.

Shirani, B., Khodambashi, M., Fallah, S., and Shahraki.A. D. 2015. Effects of Foliar Application of Nitrogen, Zinc and Manganese on Yield, Yield Components and Grain Quality of Chickpea in Two Growing Seasons. Journal of Crop Production and Processing, 5(16): 143152.

Shivay, Y. S., Prasad, R. and Pal. M. (2014a). Genetic Variability for zinc use efficiency in chickpea as influenced by zinc fertilization. International Journal of Bioresource and stress management, 5(1): 031-036.

Shivay, Y.S., Rajendraand P., Madan. P. (2014b).Effect of variety and Zinc application on yield, profitability, protein content and zinc and nitrogen uptake by chickpea (Cicer arietinum). Indian Journal of Agronomy, 59:317-321.

Shukla, V. and Shukla. I.C. 1994. Effect of Fe, Mo, $\mathrm{Zn}$ and $\mathrm{P}$ on Symbiotic nitrogen fixation of chickpea. Indian Journal of Agricultural Chemistry, 32:118-123.

Singh, M. and Ram.N. 1996. Effect of soil enrichment with zinc on crop yields and its replenishment in Mollisols of northern India. Agrochimica, 40:19-24.

Singh, U. and Yadav. D. S. 1997.Studies on sulphur and zinc nutrition on green gram in relation to growth attributes, seed, protein and $\mathrm{S}, \mathrm{Zn}$ uptake. Legume Research, 20: 224-226.

Singh, G. J. and Singh, W. S. 2014. Effect of foliar application of iron, zinc and manganese on direct seeded aromatic rice (Oryza sativa). Indian Journal of Agronomy, 59(1): 80-85.

Singh, U., Praharaj, C. S., Singh, S. S., Bohra, A. and Shivay, Y. S. (2015a). Biofortification of Pulses: Strategies and Challenges. In: Proceedings of the Second International Conference on BioResource and Stress Management, Hyderabad, India. pp. 50-55.

Singh, V., Javed, A., Kumar, A. and Chauhan.T.M. (2015b). Productivity, nutrient uptake and economics of wheat (Triticum aestivum) under potassium and zinc nutrition. Indian Journal of Agronomy, 60(3):426-430.

Singh, U., Kumar, N., Praharaj, C.S., Singh, S.S. and Kumar. L. (2015c).Fertifortification: An easy approach for nutritional enrichment of chickpea. The Ecoscan, 9(1-2):1-6.

Subbiah, B. V. and Asija, G. L. 1956.A rapid procedure for the estimation of available nitrogen in soil. Current Science, 25:259- 
260.

Tayade, B.B., Mahadik, M.K. and Jadhav. J.G. 2016. Studies on Influence of Zinc and Iron on Growth, Flowering, Yield and Quality of Annual Chrysanthemum. Advances in Life Sciences, 5(11):47114715.

Tripathi, S., Sridhar, V., Jukanti, A. V., Suresh, K.,Rao, B. V., Gowda. C. L. L. and Gaur, P. M. 2012.Genetic Variability and Interrelationships of Phenological, Physicochemical and Cooking Quality Traits in Chickpea. ICRISAT, Patancheru, Hyderabad.

Thavarajah, D. and Thavarajah, P. 2015. Will selenium increase lentil (Lens culinaris Medik) yield and seed quality. Frontiers in Plant Sciences, 6:356.

Umamaheswari, P. and Singh. C. P. 2002. Influence of irrigation levels and micronutrients ( $\mathrm{Fe}$ and $\mathrm{Zn})$ on yield and yield attributes of rajmash (Phaseolus vulgaris L.). Legume Research, 25(2):121-123.

Valenciano, J.B., Boto, J.A. and Marcelo. V. 2010. Response of chickpea (Cicer areitinum L.) yield to Zinc, Boron and Molybdenum application under pot conditions. Spanish Journal of Agricultural Research, 8(3):797-807.

Valenciano, J.B., Boto, J. A., Marcelo. V. 2011. Chickpea (Cicer areitinum L.) response to Zinc, Boron and Molybdenum application under field conditions. New Zealand Journal of crop and Horticultural Science, 39(4):217-229.

Welch, R. M. and Graham. R.D. 2004. Breeding for micronutrients in staple food crops from human nutrition prospective.
Journal of Experimental Botany, 55:353364.

Welch, R. M, Graham.R.D. 2005. Agriculture: the real nexus for enhancing bioavailable micronutrients in food crops. Journal of Trace Elements in Medicine and Biology 18:299-307.

White, P. J. and Broadly.M. R. 2005. Biofortifying crops with essential mineral elements. Trends in Plant Science, 10:588 593.

White, P.J. and Broadley. M.R. 2009. Biofortification of crops with seven mineral elements often lacking in human diets- Iron, Zinc, Copper, calcium, magnesium, selenium and iodine. New phytologist, 182:49-84.

Yadav, G. S., Kumar, D., Shivay, Y. S. and Singh. H. 2010. Zinc-Enriched Urea Improves Grain Yield and Quality of Aromatic Rice. Better Crops, 94(2):21-24.

Ya-jie, Z., Jing-jing, H., Ya-chao, L., Yingying, C. and Jian-chang, Y. 2012. Effect of phosphorus on grain quality of upland and paddy rice under different cultivation. Rice Science, 19(2):135-142.

Yip, R. 2002. Prevention and control of iron deficiency: policy and strategy issues. Journal of Nutrition, 132(4):802-805.

Yousauf, M. N., Islam, M. S., Karim. A. J. M. S. and Rahman. M. M. 2007. Fruit yield response of okra at different levels of Phosphorus and Zinc. Annals of Bangladesh Agriculture, 11(2):11-19.

Zhao, A., Lu, X., Zihui, C., Tian, X. and Yang. X. 2011. Zinc Fertilization Methods on Zinc Absorption and Translocation in Wheat. Journal of Agricultural Science, 3(1):31-33.

\section{How to cite this article:}

Brij Nandan, B. C. Sharma, Gurdev Chand, Akhil Verma, Kapilashiv Bazgalia and Rakesh Kumar. 2020. Nutritional Security Options through Agronomic Bio-fortification of Zinc and Iron in Chickpea under Rainfed Areas for Poor and under Nourished Masses of South East Asia-A Review. Int.J.Curr.Microbiol.App.Sci. 9(09): 1552-1576. doi: https://doi.org/10.20546/ijcmas.2020.909.196 